\title{
Decision theory in sustainable supply chain management: a literature review
}

\author{
Anthony Alexander, Helen Walker and Mohamed Naim \\ Cardiff Business School, Cardiff University, Cardiff, UK
}

\begin{abstract}
Purpose - This study aims to aid theory building, the use of decision theory (DT) concepts in sustainable supply chain management (SSCM) research is examined.

Design/methodology/approach - An abductive approach considers two DT concepts, Snowden's Cynefin framework for sense-making and Keeney's value-focussed decision analysis, in a systematic literature review of 160 peer-reviewed papers in English.

Findings - Around 60 per cent of the papers on decision-making in SSCM come from operational research (OR), which makes explicit use of DT. These are almost all normative and rationalist and focussed on structured decision contexts. Some exceptions seek to address unstructured decision contexts via Complex Adaptive Systems or Soft Systems Methodology. Meanwhile, a second set, around 16 per cent, comes from business ethics and are empirical, behavioural decision research. Although this set does not explicitly refer to DT, the empirical evidence here supports Keeney's value-focussed analysis.

Research limitations/implications - There is potential for theory building in SSCM using DT, but the research only addresses SSCM research (including corporate responsibility and ethics) and not DT in SCM or wider sustainable development research.

Practical implications - Use of particular decision analysis methods for SSCM may be improved by better understanding different decision contexts.

Social implications - The research shows potential synthesis with ethical DT absent from DT and SCM research.

Originality/value - Empirical behavioural decision analysis for SSCM is considered alongside normative, rational analysis for the first time. Value-focussed DT appears useful for unstructured decision contexts found in SSCM.

Originality/value - Empirical, behavioural decision analysis for SSCM is considered alongside normative rational analysis for the first time. Value-focussed DT appears useful for unstructured decision contexts found in SSCM.
\end{abstract}

Keywords Strategy, Decision-making, Ethics, Supply chain management, Business ethics, Sustainability, Corporate responsibility, Operational research, Decision theory, Sustainable supply chains, Cynefin

Paper type Literature review

\section{Introduction: sustainable supply chain management, from why to how}

Sustainable development has gained an increasingly mainstream profile in recent years. Some 25 years after the definition in Brundtland (1987), many businesses accept it as a board-level concern (Haanaes et al., 2011). This prompts questions about how sustainability should be put into practice. In other words, how it should be incorporated into strategic and operational levels of management decision-making. Internally to an organisation, this is studied as "sustainable operations management" (Gimenez et al., 2012), and externally to an organisation, the impacts associated with the value chain and supply network are studied by "sustainable supply chain management" (SSCM) (Carter and Rogers, 2008; Lamming and Hampson, 1996).

The current issue and full text archive of this journal is available at www.emeraldinsight.com/1359-8546.htm

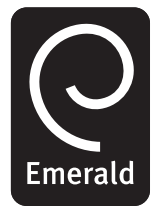

Supply Chain Management: An International Journal 19/5/6 (2014) 504-522

Emerald Group Publishing Limited [ISSN 1359-8546] [DOI 10.1108/SCM-01-2014-0007]
While Supply Chain Management: An International fournal recently published the special issue on "Measuring and Managing Sustainability Performance in Supply Chains" (Vol. 19, No. 3), and previously, "Decision Making and Analysis within Supply Chains" (Vol. 15, No. 4), this research seeks to bring the two topics closer together. How sustainability is variously defined and perceived in strategic (C) Anthony Alexander, Helen Walker \& Mohamed Naim. Published by
Emerald Group Publishing Limited. This article is published under the
Creative Commons Attribution (CC BY 3.0) licence. Anyone may
reproduce, distribute, translate and create derivative works of this article
(for both commercial \& non-commercial purposes), subject to full
attribution to the original publication and authors. The full terms of this
licence may be seen at http://creativecommons.org/licences/by/3.0/
legalcode.

The authors are grateful to the UK Economic and Social Research Council (ESRC), the Society for the Advancement of Management Studies (SAMS) and the British Academy of Management (BAM) for helping fund this research. An early version was presented at the IPSERA 2013 conference. The authors also thank the anonymous reviewers for their comments.

Received 6 January 2014

Revised 12 May 2014

30 June 2014

Accepted 1 July 2014 
and operational terms, both internally and externally, are important considerations for implementing SSCM. As shown by Hassini et al. (2012), a wide range of social and environmental metrics are used by organisations, reflecting the breadth of topics sustainability can encompass in different organisations. Although grounded theory research from Pagell and Wu (2009) and Wu and Pagell (2011) has begun to explore the subject of decision-making in SSCM via empirical case study research, this has not done so with explicit reference to decision theory (DT). Similarly, SCM research that does address contemporary DT such as Wong and Acur (2010) does not consider characteristics central to SSCM.

DT directly relates to many concepts mentioned in SSCM research. Requirements for successful SSCM include organisational culture, strategy, risk management and transparency (Carter and Rogers, 2008), all of which affect the nature of decision-making. Meanwhile, challenges to successful SSCM include uncertainty, complexity, operationalisation, cost and mindset and cultural change (Abbasi and Nilsson, 2012). Collaboration is a key driver, so inter-firm decision-making processes are important (Gimenez and Tachizawa, 2012). While various papers focus on modelling SSCM criteria using operational research (OR) decision analysis (Bloemhof-Ruwaard et al., 1995; Seuring, 2013), these represent one particular branch of the wider subject of DT.

As such, there appears to be a gap around the detailed discussion of DT in existing SSCM research. Hence, there is an opportunity for a systematic review to see what references have been made across a broad spectrum of DT and from this seek to build theory for SSCM. The research conducted here therefore seeks to answer the specific question:

How is the subject of decision-making addressed in academic research on sustainable supply chains?

Decision-making in SSCM is explored using the comprehensive overview of DT provided by French et al. (2009). As far as we are aware, DT has not been adopted in any previous literature reviews of SSCM. An abductive approach (Dubois and Gadde, 2002; 2010; Kovács and Spens, 2005) is taken to address both the theoretical foundation offered, and also to identify how well references to decision-making in SSCM literature fit with particular DT typologies and other related concepts. Results are classified using two aspects of DT. First, Snowden's Cynefin framework for sense-making (Kurtz and Snowden, 2003) provides a typology based on the structural context of the SSCM decision. Second, Keeney's distinction between alternative-focussed decision-making and value-focussed decision-making is considered (Keeney, 1996). Papers are also assessed for their level of analysis: dyadic, triadic, multi-tier or whole network.

The structure of the paper is as follows. The next section describes DT and different applications. Then, the research method of systematic literature review and the research protocol adopted are outlined. The results of the search and basic analysis are presented, followed by a discussion of the findings. Finally, conclusions are drawn, with implications for management practice and further academic research.

\section{An overview of DT: rational and behavioural analyses}

French et al. (2009) explain the historic evolution of DT in management, the basic toolkit of DT and where different tools are appropriate to improve decision-making. These include individual and group decisions, "decision tables" showing different options and their known consequences, "decision trees" that show how particular options open up others, and "influence diagrams" that show conditional dependency or independency. Further techniques include Analytic Hierarchy Process (AHP) and Multiple-Criteria Decision Analysis (MCDA), which concern the weighing of options to reveal the significance of different choices. Analytic Network Process (ANP) concerns how such factors may affect each other. Multiple Integer Linear Programming (MILP) determines optimum outputs by analysing relationships between many variables. Use of these tools has benefited greatly from progress in computing power and they have become a standard part of the operations of many organisations. However, although potentially providing valuable insight, additional factors to consider include the accuracy of the underlying assumptions and data and issues around implementation.

One of the seminal works of DT in management is Simon (1960), which introduces the concept of "bounded rationality". As described by French et al. (2009), this can be seen as initiating a new branch in DT. While the incumbent rational approach to management decision-making was normative, explaining how we ought to best make decisions (central to the traditional field of OR), Simon (1960) began exploring the behavioural branch, exploring how decisions are made in reality. This is a major research topic in psychology and political science.

As Simon (1960) explains, under classical economic theory agents are assumed to act in a rational way and options are prioritised according to what the expected utility, or benefits, are. This is called the Subjective Expected Utility model. Traditional OR applies such economic modelling to sophisticated problems of management and operations in a scientific way, seeking optimal solutions. According to French et al. (2009, p. 141), this tradition started to change in the 1980s and 1990s with the rise of "Soft OR", but "Hard OR" still dominates the field today.

In contrast to the strictly rational view of $\mathrm{OR}$, bounded rationality describes how people are limited in their logical reasoning capabilities and subject to various biases in perception. These include "issue framing", "evaluation", "perception of risk and probability", "institutional pressure" and "heuristic short-cuts". The formal study of these is called behavioural decision analysis. For example, Statman and Caldwell (1987) show how political pressures can over-ride rational analysis in disinvestment decisions. Evidence from the disc-drive industry showed how non-rational behavioural factors could bring down whole companies.

Also, "prospect theory" shows that when things are going badly people's aversion to risk goes down, so they make riskier decisions. Under conditions of stress, our decision-making capability can thus become impaired and so emotional states are as significant as rational capability. A detailed account of 
the effect of this in the 2008 financial crash is provided by Tett (2009).

French et al. (2009) explain how the rational normative branch and behavioural empirical branch can be brought together using what they call "prescriptive decision analysis". This considers contextual bias facing a specific decision-maker alongside rational decision processes so as to counter cognitive limitations and biases. However, it must be remembered that all such techniques are merely "decision support systems" to help inform the judgement of a decision-maker. Responsibility for taking a decision must remain with the individual or group holding authority. Decision models are, to quote Pidd:

[. . .] tools for thinking [. . .] ad hoc exploratory devices for reflection before action [. . .] A model intended as a tool for thinking needs to be adequate for the task, and it must be skilfully used if the task is to be done well (Pidd, 1999, p. 120)

As noted by Simon (1960), and further explored by Mintzberg (1972a, 1972b) and Jaques (1989), there is a link between organisational hierarchy and the characteristics of decisions. Strategic decisions tend to be unstructured, having to consider multiple factors, uncertainty and change (Figure 1). Strategic decisions are longer-term, so it may take time before success is apparent. They are important, have a low frequency or are unique and non-repeating and thus are unstructured. In contrast, operational decisions are more definable, stable or structured and, thus, amenable to programming. Corporate strategy is about setting long-term goals, while the tactical and operational level does the detailed work to try to meet those goals. Less quantitative, predictive and more general management models may be used to aid unstructured decision problems. Porter's Five Forces, for instance, is fundamentally a decision model operating in the "unstructured domain" of corporate strategy (French et al., 2009; Porter, 1985), where indicative rather than necessarily quantifiable outputs aid decision-making. Stakeholder analysis is another where, for instance, Mitchell et al. (1997) describe the identification of various parties who can influence organisational strategy to decide which are the most significant.

In contrast, in OR the use of sophisticated rational normative decision tools allows comparison of many different options or different objectives, provided that the problem is structured, and the variables can be accurately coded and analysed. While AHP, ANP, MCDA and MILP (see definitions above) all require structured decision problems, recent developments suggest greater degrees of ability in

\section{Figure 1}

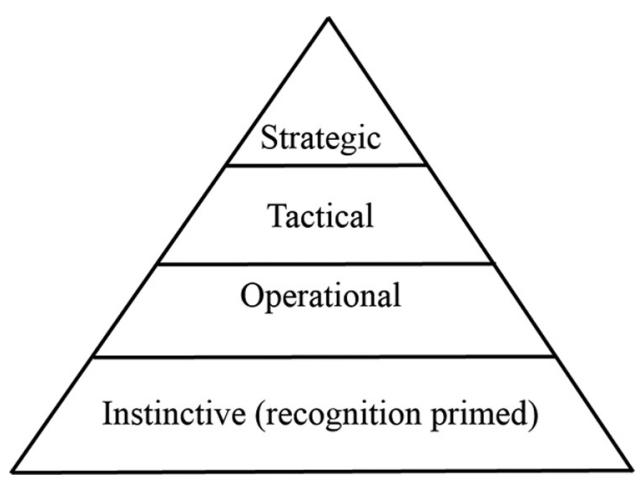

working with unstructured contexts. These include "Expert Systems", “Artificial Intelligence", "Artificial Neural Networks" and "Genetic Algorithms". However, these are still best suited to dealing with structured problems where all relevant factors can be easily coded and have attributes that are unambiguous, comprehensive, understandable and operational (Dekker et al., 2012; French et al., 2009; Keeney and Gregory, 2005).

Similarly, recent SCM research into Complex Adaptive Systems (Bellamy and Basole, 2013; Breite and Koskinen, 2014; Che et al., 2010; Pathak et al., 2014) or use of fuzzy logic, rough set theory or grey systems (Bai and Sarkis, 2010a, $2010 \mathrm{~b}$ ) seek new approaches to structured and unstructured contexts. A key question is to what extent they deal with specific "knowns" (such as level of probability or uncertainty as to precise levels of a variable) to impose a form of structure on unstructured contexts. Such developments show a need for greater understanding of the underlying theoretical foundations at work and how these relate to sustainability.

Systems Theory provides one such foundation, with structured decision contexts equivalent to "closed systems" (Checkland, 1972, 1983). Assuming the structure of the system is stable, if the key attributes are known and measurable, then a predictive OR model can be generated, enabling the comparison of various alternative options so preferred outputs can be calculated and put into practice (Dekker et al., 2012). However, in SSCM, management decisions may be characterised by multiple stakeholders, multiple criteria and uncertainty as to present or future circumstances, as well as having strategic significance, and hence are complex and unstructured (Büyüközkan and Çifçi, 2012; French and Geldermann, 2005).

\subsection{Snowden's Cynefin framework and Keeney's value- focussed analysis}

A further recent addition to the DT canon, building on mathematical theories of complex and chaotic systems, is the Cynefin framework (Kurtz and Snowden, 2003; Snowden, 2002; Snowden and Boone, 2007), shown in Figure 2. This is a knowledge management sense-making framework that provides a typology distinguishing between structured and

\section{Figure 2}

\section{Unstructured / soft systems}

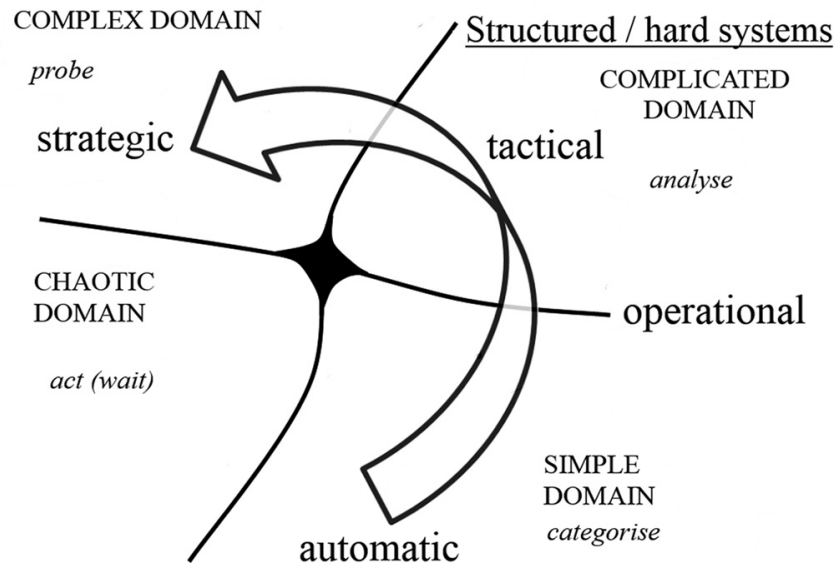


unstructured decision contexts. The structured domain is stable and ordered, where cause and effect can be determined. The simple, "known" domain includes standard operating procedures, but in the complicated, "knowable" domain cause and effect are not readily apparent. However, they can be determined by expert analysis and so are separated by time. This is the realm of classical economics, traditional $\mathrm{OR}$ and System Dynamics.

Against this are set the unstructured, complex and chaotic contexts. In the complex domain there are many inter-relating influences but order is emergent. It is a decision context characterised by inherent uncertainty but patterns do appear. This order is not quantifiably predictable in advance, but cause and effect can be determined in retrospect. Finally, the chaotic realm is also unstructured, but there is no emergent order. Snowden and Boone (2007) discuss the management implications of each decision context. Faced with a chaotic environment, leaders may seek to impose order, set a direction for travel with a hand on the tiller, or simply wait for the system context to stabilise back into one of the other realms. This correlates to the strategic domain of decision-making, where behavioural instinct and long-term strategic vision and guiding values can be more practical than rational analysis.

The Cynefin framework provides a pragmatic overview that reminds us that when facing a decision, we must be mindful that the type of decision context has a major influence on how it should be approached. As a knowledge management tool, it assists in prescriptive decision-making (French, 2012; French et al., 2009). We adopt the Cynefin framework as a typology against which to consider the types of decision-making discussed in SSCM research papers.

We also consider the literature from the perspective of Keeney's values-focussed thinking, which is an additional way of addressing both unstructured contexts and structured, complicated contexts that are prohibitively expensive to solve. As this is based on alignment to principles and objectives, rather than choosing between alternatives, it provides a way to better understand the role of values in business sustainability, and a means to build theory around decision-making. It is a form of decision-making heuristic, also known as a "rule of thumb" or "principle-based" rather than "rule-based" decision tool. Keeney (1996) suggests that organisations that adopt clear values are able to respond better to strategic issues, especially under conditions of uncertainty, than those reliant on alternatives-focussed decision-making, which relies on clearly defined attributes. Values shape the acceptable end-states or objectives the decision-maker seeks, without creating a structured set of rules:

Conventional approaches to decision making focus on alternatives. However, alternatives are relevant only because they are means to achieve values. Therefore, thinking about decision situations should begin with values. Value-focused thinking describes and illustrates concepts and procedures for creating better alternatives for your decision problems, identifying decision opportunities more appealing than the decision problems that confront you, and articulating and using your fundamental values to guide and integrate your decision making activities Keeney (1996, p. 537).

The best thing for an organisation to do is to invest in developing a clear understanding of its strategic objectives and values. Alternatives can then be compared against these and if necessary all can be rejected and different approaches sought. So, in summary, Keeney (1996) provides a heuristic method
Figure 3

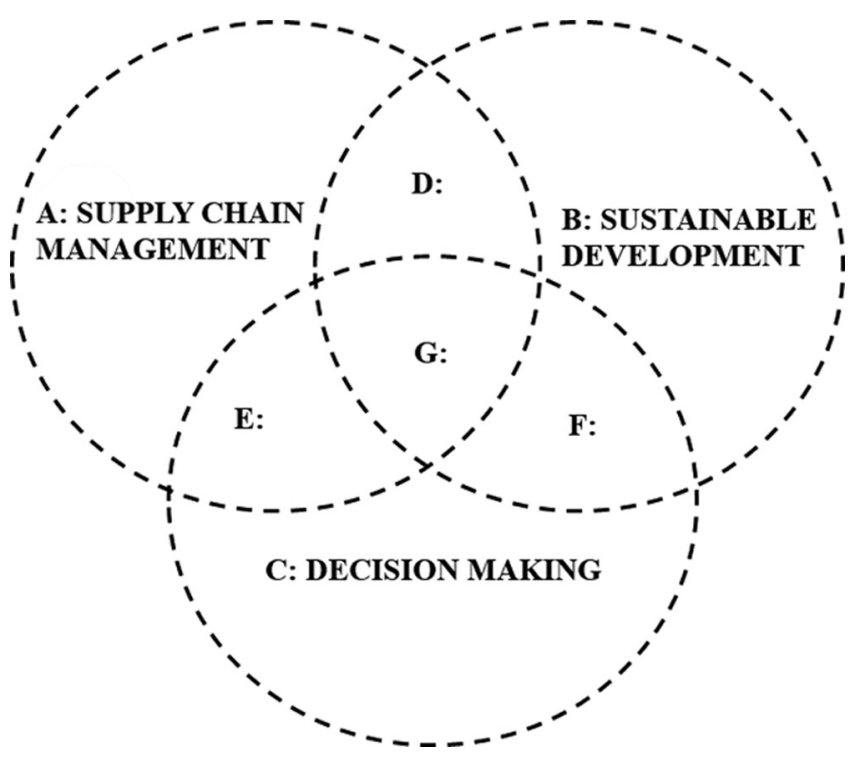

for addressing difficult decisions, and contemporary Systems Theory offers a means to understand the nature of those decisions, as described using the Cynefin framework. Figure 2 shows the link between decision-making, decision context and organisational structure. Keeney shows that an alternatives-focus may be sufficient in the structured domains, but values-focus may be effective in the unstructured domains or in the structured complicated domain if the cost of analysis is prohibitive. Structured decisions, where the alternativesfocus applies, benefit from clearly defined, unambiguous attributes (Keeney and Gregory, 2005) and so, as shown in Figure 4, metrics and reporting standards are relevant for SSCM

\section{Figure 4}

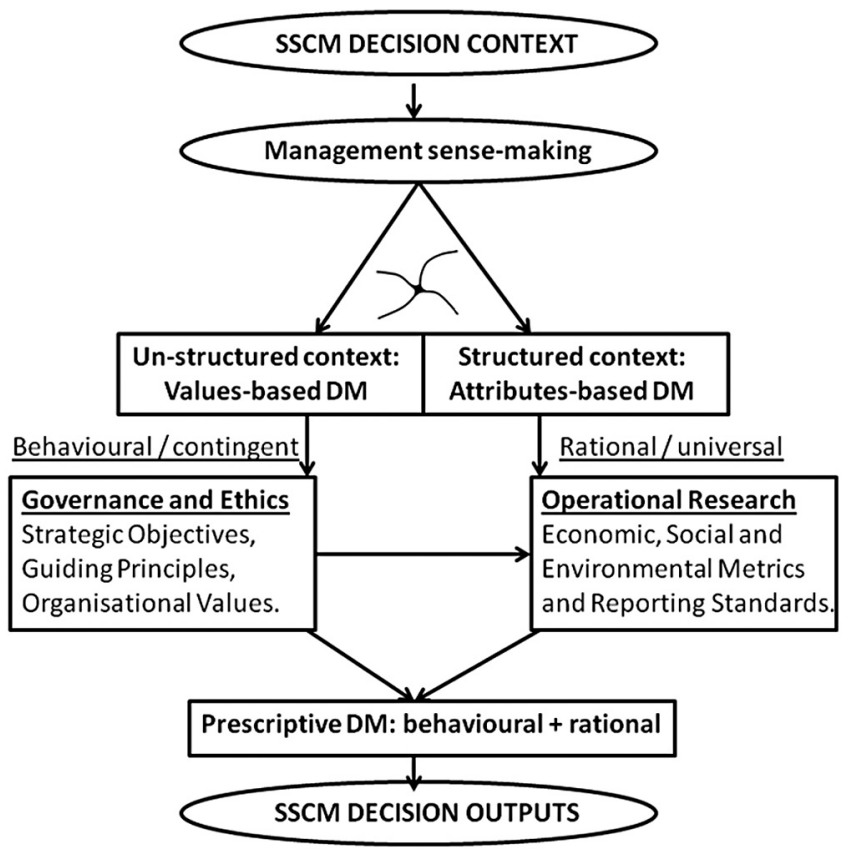


decisions in this space. However, if the decisions are unstructured, guiding principles or values may apply, so organisational culture and leadership become highly significant for SSCM. The conceptual model in Figure 4 is discussed in more detail in Section 6, below. The next sections explore the extent to which Snowden's and Keeney's DT concepts are reflected within SSCM research on decision-making.

\section{Research method: systematic literature review}

The research adopts the systematic literature review method of Tranfield et al. (2003). This takes the rigorous approach to literature reviews developed in medical research and applies it to management research. It aims at a peer-reviewed, well recorded and thus replicable process to help achieve comprehensive coverage, relevance to practice and the removal of researcher bias possible with narrative literature reviews. Once the need for a review is identified, a research protocol is defined and recorded, search strings established, selection and de-selection criteria defined, and then selected papers assessed and outputs synthesised. Finally, the process considers the relevance to particular problems, treating management issues as fundamentally about practical application, as medical research is.

The planning for the review involved the assembling of an expert panel of six people, three academics experienced in OR, $\mathrm{OM}$ and SCM and three practitioners working in sustainable business and SCM. The panel advised on the overall research design and choice of search terms, and consultation on the initial proposal led to revisions. A scoping study was conducted, with a smaller set of search terms and only a single database queried. The results helped to further refine the final literature review process. In particular, certain search terms were added or dropped depending on the nature of the results provided. This is described in more detail in the paragraphs below. In line with Tranfield et al. (2003), the Research Protocol is detailed in Table I to allow other researchers to replicate the review process.

The scoping study showed, first, that in addition to the use of the term "Sustainable Supply Chain Management", there are also a range of broadly synonymous terms used by different scholars. These include "Green Supply Chain Management" (GSCM), "Environmental Purchasing and Supplier Management" (EPSM), "Sustainable Supply Chain Governance" (SSCG), "Corporate Social Responsibility (CSR) and Purchasing" and "Supply Chain Management Ethics" (SCM-Ethics). Hence, a wider range of search terms was included. These reflect the use of the words "green" or "ecological" to refer to environmental sustainability, the words "responsible/responsibility" for corporate social responsibility and "ethics/ethical" to capture social sustainability, plus the "triple bottom line" as a common business phrase related to Sustainable Development.

Second, the scoping study found that although the topic was primarily discussed in operations management journals, there was also relevant research published in corporate responsibility, business ethics, strategy and general management journals, as well as sector-specific journals. Given that SSCM is a relevant topic of concern for a range of academic disciplines, and is also a recent area of research, relevant and high-quality evidence and theory may be found in papers outside of any specific field. Hence, this research does not select on the basis of journal titles.

\subsection{Defining the field of study}

Figure 3 shows the focus of this research as the overlap between three distinct topics. SCM is a significant field in business and management scholarship that has been growing over the last thirty years or so. Sustainable Development is a separate topic growing from environmental science and political studies, international development and ethics. Where these two overlap, we find the study of SSCM and similar related terms such as environmental purchasing or ethical procurement. A lack of categorical definition is common in young areas of study. Third, we have decision-making, which is labelled as such to capture empirical papers examining decision-making that do not explicitly relate to DT, such as Pagell and Wu (2009).

Although the specific area of focus is Section G, the search terms used captured a wealth of interesting papers in Sections D, $\mathrm{E}$ and $\mathrm{F}$. These were excluded from the main results though would be areas worth exploring in future research. Finally, there is, of course, a substantial range of research which although relating to only one of the areas of supply chains, sustainability or decision-making (Sections $\mathrm{A}, \mathrm{B}$ and $\mathrm{C}$ ), may contribute further insight into the topic of SSCM and DT. These are also outside the scope of this study but could be investigated by future research.

A further point in relation to the plurality of terms directly relevant to SSCM, including the terms "Corporate Social Responsibility" (CSR) and "Ethics", is that "Sustainable Development" is not a categorical or coherent field. Criticisms of the definition and evolution of the Sustainable Development concept, such as Littig and Griessler (2005) or Robinson (2012), point to an enthusiasm for the term that exceeds the robustness of its theoretical foundations. The meaning of social sustainability is a particular aspect of this, where it can be taken as linked to human rights, and thus to business ethics. Hence, there is far more conceptual depth here than implied by Section B of Figure 3.

However, there is a relatively small volume of research contained in the overlap between decision-making, supply chains and ethics, plus CSR, plus sustainability; and there is a clear link between ethics, CSR and sustainability, so these are treated as analogous here. This helps create an interdisciplinary frame of reference regarding decision-making that is missing from reviews such as Seuring (2013), and a broader more holistic frame regarding sustainability that is missing from OR papers that address only a single environmental metric, such as carbon emissions, alongside conventional economic optimisation. Ethical decision-making has its own set of distinct associations and a rich discourse independent of DT, notably in marketing, psychology, corporate governance and leadership studies. However, this is also excluded from the scope of this study.

For the sake of repeatability, under the requirements of the systematic review process (Tranfield et al., 2003), everything that passes the selection criteria is included here. The result is 
Table I Research protocol

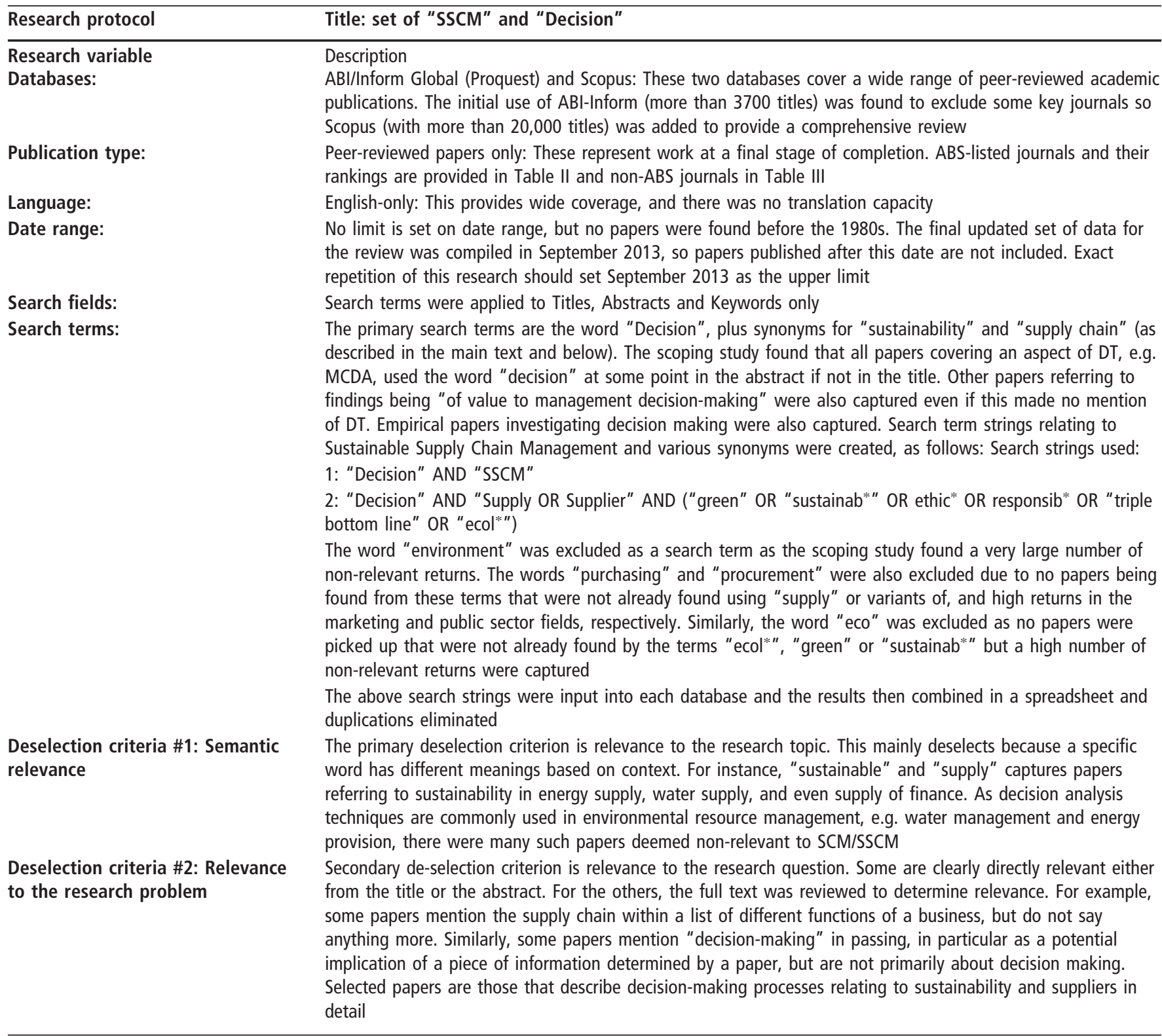

a selection that although systematic, is somewhat eclectic. This is potentially serendipitous. SSCM is revealed as a classic messy problem (Mackenzie et al., 2006; Rittel and Webber, 1973). As shown by Chicksand et al. (2012), SCM lacks coherence necessary for it to be a scientific discipline. Extending its range of concern into social and environmental factors inherently entails bringing in additional perspectives, including ones of political value judgements, which although directly relevant, produce further plurality and heterogeneity. Such a non-partisan perspective to the literature is interdisciplinary and, as discussed in Tranfield et al. (2003) and Denyer et al. (2008), this increases the opportunities for synthesis to occur, and thus the potential for creative solutions and new theory to emerge. As discussed in Section 2, above, the lenses applied for such theory building here are Kurtz and Snowden (2003) and Keeney (1996).

\section{Basic findings and analysis}

\subsection{Categorisation by journal title and Association of Business Schools rank}

Applying the systematic literature review Research Protocol shown in Table I yielded 1,069 papers, of which 160 were deemed relevant and given detailed review (909 were therefore deselected as non-relevant, according to the protocol in Table I). The first stage of analysis is to look at where these papers are published. Table II shows the number of papers in journal titles that are included in the UK Association of Business Schools (ABS) fournal list and their ABS ranking (Harvey et al., 2011). This is used as a measure of journal quality in the UK, but does not necessarily include journals in other relevant fields, such as engineering, computing or political science. The highest level of the ranking system is 4, representing work of world-leading quality. Rank 3 is 
Table II ABS-ranked research relevant to SSCM and decision making

\begin{tabular}{|c|c|c|c|}
\hline ABS subject classification & ABS rank & Number of papers & Journal title \\
\hline \multirow[t]{13}{*}{ Operations, Technology and Management } & 4 & 1 & Journal of Operations Management \\
\hline & 3 & 2 & IEEE Transactions on Engineering Management \\
\hline & 3 & 17 & International Journal of Production Economics \\
\hline & 3 & 12 & International Journal of Production Research \\
\hline & 3 & 2 & Production and Operations Management \\
\hline & 3 & 5 & Production Planning and Control \\
\hline & 3 & 6 & Supply Chain Management: An International Journal \\
\hline & 2 & 1 & Computers \& Industrial Engineering \\
\hline & 2 & 1 & International Journal of Logistics Management \\
\hline & 2 & 4 & International Journal of Physical Distribution and Logistics Mgt. \\
\hline & 2 & 2 & Journal of Purchasing and Supply Management \\
\hline & 1 & 1 & Business Process Management Journal \\
\hline & 1 & 1 & International Journal of Agile Systems and Management \\
\hline Operations Research and Management & 4 & 1 & Management Science \\
\hline \multirow[t]{6}{*}{ Science } & 3 & 1 & Decision Sciences \\
\hline & 3 & 7 & European Journal of Operational Research \\
\hline & 3 & 1 & OR Spectrum \\
\hline & 3 & 2 & The Journal of the Operational Research Society \\
\hline & 2 & 3 & Computers and Operations Research \\
\hline & 2 & 1 & Interfaces \\
\hline \multirow[t]{5}{*}{ Business Ethics and Governance } & 3 & 1 & Business Ethics Quarterly \\
\hline & 3 & 6 & Journal of Business Ethics \\
\hline & 2 & 1 & Business Ethics: A European Review \\
\hline & 1 & 1 & Corporate Reputation Review \\
\hline & 1 & 1 & $\begin{array}{l}\text { Corporate Social Responsibility and Environmental } \\
\text { Management }\end{array}$ \\
\hline \multirow[t]{3}{*}{ Sector Studies } & 3 & 1 & $\begin{array}{l}\text { Transportation Research Part E, Logistics and Transportation } \\
\text { Review }\end{array}$ \\
\hline & 2 & 1 & Journal of Environmental Management \\
\hline & 1 & 1 & British Food Journal \\
\hline \multirow[t]{3}{*}{ Social Science } & 4 & 1 & Environment and Planning A \\
\hline & 3 & 1 & Technological Forecasting and Social Change \\
\hline & 2 & 3 & Journal of Industrial Ecology \\
\hline \multirow[t]{2}{*}{ Economics } & 4 & 1 & Journal of Environmental Economics and Management \\
\hline & 3 & 1 & Ecological Economics \\
\hline \multirow[t]{2}{*}{ Strategic Management } & 4 & 2 & Strategic Management Journal \\
\hline & 2 & 1 & Business Strategy and the Environment \\
\hline \multirow[t]{2}{*}{ General Management } & 3 & 1 & MIT Sloan Management Review \\
\hline & 1 & 2 & Management Decision \\
\hline Information Management & 3 & 3 & Decision Support Systems \\
\hline Organisation Studies & 2 & 1 & Journal of Knowledge Management \\
\hline Public Sector Management & 3 & 1 & Journal of Public Policy and Marketing \\
\hline \multicolumn{4}{|l|}{ Entrepreneurship and Small Business } \\
\hline Management & 1 & 1 & Journal of International Entrepreneurship \\
\hline
\end{tabular}

defined as providing original, well-executed and well-regarded research. Ranks 1 and 2 are seen as providing original research of a recognised and acceptable standard, respectively (Harvey et al., 2011). A total of 41 ABS-listed titles are found, containing 103 papers.

An assessment of the quality of non-ABS ranked journals is not included here. It is left up to readers to determine the quality or relevance of papers published in non-ABS ranked journals. However, as these include sector-specific journals or non-business and management journals that nevertheless may provide high-quality useful research, they are all included. This approach acknowledges the multi-disciplinary nature of SSCM as a research topic and the variety of scholars considering it. There are 43 non-ABS listed journals found, containing a total of 57 papers.

\subsection{Categorisation of papers}

Four levels of categorisation from the systematic literature review are included. First, is a listing of papers by the type of decision conducted (Table IV). This may be of benefit to 
Table III Non-ABS journal titles by number of papers

\begin{tabular}{|c|c|c|}
\hline $\begin{array}{l}\text { Papers } \\
\text { per title }\end{array}$ & $\begin{array}{c}\text { Total } \\
\text { papers }\end{array}$ & \\
\hline 9 & 9 & Journal of Cleaner Production \\
\hline 3 & 3 & $\begin{array}{l}\text { International Journal of Logistics Systems and } \\
\text { Management }\end{array}$ \\
\hline 2 & 8 & $\begin{array}{l}\text { Applied Mathematical Modelling; Clean } \\
\text { Technologies and Environmental Policy; Greener } \\
\text { Management International; Management } \\
\text { Research Review }\end{array}$ \\
\hline 1 & 37 & $\begin{array}{l}\text { Asia Pacific Management Review; Business and } \\
\text { Society; Computers in Industry; Ecological } \\
\text { Indicators; Economic Systems Research; } \\
\text { Engineering Optimization; Environmental } \\
\text { Science \& Technology; IIMB Management } \\
\text { Review; Information Management and Business } \\
\text { Review; International Food and Agribusiness } \\
\text { Management Review; International Journal of } \\
\text { Electronic Business Management; International } \\
\text { Journal of Management \& Decision Making; } \\
\text { International Journal of Services and Operations } \\
\text { Management; International Journal of Services } \\
\text { Technology and Management; International } \\
\text { Journal of Simulation and Process Modelling; } \\
\text { International Journal of Sustainability in Higher } \\
\text { Education; International Journal of Sustainable } \\
\text { Manufacturing; International Journal of } \\
\text { Operational Research; Journal of Agricultural } \\
\text { and Environmental Ethics; Journal of } \\
\text { Agricultural and Food Industrial Organization; } \\
\text { Journal of Applied Management and } \\
\text { Entrepreneurship; Journal of Fashion Marketing } \\
\text { and Management; Journal of Hospital } \\
\text { Marketing and Public Relations; Journal of } \\
\text { Industrial Engineering and Management; } \\
\text { Journal of Information and Computational } \\
\text { Science; Journal of Marketing Channels; Journal } \\
\text { of Public Procurement; Journal of Scientific and } \\
\text { Industrial Research; Leadership and } \\
\text { Management in Engineering; Optimization; } \\
\text { Progress in Industrial Ecology; Resources, } \\
\text { Conservation and Recycling; Science and } \\
\text { Engineering Ethics; Social Responsibility } \\
\text { Pournal; Sustainability; WSEAS Transactions on } \\
\text { Pont Resources and Environment }\end{array}$ \\
\hline
\end{tabular}

researchers interested in particular SSCM decision types, but these are only selections from the data set and not comprehensive accounts of such types of decision.

Second, the papers are classified based on the type of research and decision-making method. This divides the set between normative rational studies and empirical behavioural studies. These are also classified according to their academic subject areas, notably the OR branch and Business Ethics branch. Some normative studies describe the logic of a modelling process then seek to validate it through application to a single case study. These are not classified as primarily empirical studies. Pagell and Wu (2009), in contrast, explores how practitioners address uncertainty in their SSCM decision-making processes, and so is an example of primarily empirical research. In addition, there are a small number of general reviews or conceptual papers that concern SSCM decision-making, which are classified as miscellaneous.

From the 160 papers, exactly 100 are classified as OR, of which 97 are normative rational decision models, with three papers providing literature reviews, so classified as general. Eighteen papers are from Business Ethics, seven of which are empirical behavioural studies, seven are normative rational models and the remaining four are classed as general. A further 41 papers are classified as Others, consisting largely of Operations Management or Supply Chain Management research. Of these, 20 papers are empirical behavioural decision research, 6 are normative rational decision models and 15 are classed as general. See Table V. One paper is classified as an exception, and this is Hirsch and Meyer (2010), which deliberately unites the OR and ethical decision analysis branches. This is discussed in Section 5 below.

Third, papers are classified according to the level of analysis. Table IV shows the main SSCM decision areas, and the level of analysis directly follows from these. Some papers, such as on supplier selection, are wholly concerned with Tier 1 links only. Here decision problems are modelled to include sustainability criteria alongside conventional SCM criteria. These papers are dyadic, but they are in the minority. Papers concerning triads or multiple tiers are also present across the topics, but are also a minority of the total. By far, the majority of papers (more than 50 per cent) are those that are concerned with the whole network level. In particular, papers examining life cycle analysis, closed loop and multi-tier network design are concerned with the extended and ultimate supply chains beyond the first tier.

This whole network approach is central to understanding environmental and social impacts further up- or downstream of the first tier. This might be thought of as a society-centric perspective, concerned with more than just the economic objectives of the focal firm. In contrast, supplier selection is fundamentally an issue of best achieving the objectives of a focal firm, and hence can be thought of as a firm-centric topic. This divide is mentioned in Cohen and Kunreuther (2007) in the context of the work of Kleindorfer, covering both macro-level environmental issues and micro-level implementation, echoing the divide between firm-centric approaches to SSCM seen in Carter and Rogers (2008) and the society-centric approach discussed in Pagell and Shevchenko (2013), the wider critique of corporate sustainability in Whiteman et al. (2012) and of the role of civil society in Lepineux (2005). A further example is seen in Reuter et al. (2012), identifying public- vs shareholder-orientation.

Finally, the papers are classified in relation to the decision contexts of the Cynefin framework. It is important to note that Kurtz and Snowden (2003) emphasise that Cynefin is a sense-making framework that should vary for each individual context in which it is applied, and that categorisation is a method only applicable to structured decision contexts. In this research, it is assumed that the results of the systematic literature review provide a closed set of structured data that is amenable to classification. This is, arguably, a simplification heuristic for the sake of theoretical exploration. 
Table IV Papers categorised by predominant SSCM decision applications

\begin{tabular}{|c|c|}
\hline SSCM decision area & References \\
\hline Pricing and cost & $\begin{array}{l}\text { Ghosh and Shah (2012), Cruz and Wakolbinger (2008), Poret and Chambolle (2007), Toktay and Wei } \\
\text { (2011), Tsai and Hung (2009) }\end{array}$ \\
\hline Inventory & Bouchery et al. (2012), Choi and Chiu (2012), El Saadany et al. (2011), Chung and Wee (2011) \\
\hline $\begin{array}{l}\text { Supply Chain/Supply Network } \\
\text { Design }\end{array}$ & $\begin{array}{l}\text { Tavella and Hjorts } \varnothing \text { (2012), Oglethorpe (2010), Albino et al. (2002), Muñoz et al. (2013), Chaabane } \\
\text { et al. (2011), Chaabane et al. (2012), Metta and Badurdeen (2013), Cruz and Wakolbinger (2008), } \\
\text { Eskandarpour et al. (2013), Ramezani et al. (2013), van der Vorst et al. (2009), Wang et al. (2011) }\end{array}$ \\
\hline Supplier Selection & $\begin{array}{l}\text { Büyüközkan and Çifçi (2011), Che et al. (2010), Lee (2008), Hsu and Hu (2009), Reuter et al. (2012), } \\
\text { Lahdesmaki (2005), Bai et al. (2010); Liao (2013), Bai and Sarkis (2010b), Kannan et al. (2008), Kuo } \\
\text { et al. (2010), Wu (2010), Kannan et al. (2013), Choi (2013), Wittstruck and Teuteberg (2012) }\end{array}$ \\
\hline Logistics & $\begin{array}{l}\text { Harris et al. (2011), Wolf and Seuring (2010), Efendigil et al. (2008), Khoo et al. (2001), Björklund } \\
\text { (2010), Dekker et al. (2012), Merrick and Bookbinder (2010), Akkerman et al. (2010), Kannan et al. } \\
\text { (2009), Bockholt et al. (2011), Jaegler and Burlat (2012), De Rosa et al. (2013), Wang et al. (2013), } \\
\text { Fritz and Schiefer (2009) }\end{array}$ \\
\hline $\begin{array}{l}\text { Environmental Management } \\
\text { (including ISO14000) }\end{array}$ & $\begin{array}{l}\text { Bloemhof-Ruwaard et al. (1995), Arimura et al. (2011), Lawrence et al. (2002), Sarkis (1998), McIntyre } \\
\text { et al. (1998) }\end{array}$ \\
\hline Supply Chain Risk Management & Cruz (2013), Wang et al. (2012a, 2012b), Cruz (2009), Giannakis and Louis (2011), Xiao et al. (2012) \\
\hline $\begin{array}{l}\text { Supplier Performance } \\
\text { Assessment }\end{array}$ & $\begin{array}{l}\text { Tachizawa et al. (2012), Sarkis et al. (2012); Zhu et al. (2010), Dai and Blackhurst (2012), Bai and } \\
\text { Sarkis (2010a), Lu et al. (2007), Wen et al. (2013) }\end{array}$ \\
\hline Life Cycle Analysis & $\begin{array}{l}\text { Lenzen (2008), Fava et al. (2009), Nelson et al. (2011), Early et al. (2009), Chaabane et al. (2012), } \\
\text { Hutchins and Sutherland (2008), Adhitya et al. (2011), Halog and Manik (2011), Hu and Bidanda } \\
\text { (2009), Tseng and Geng (2012) }\end{array}$ \\
\hline $\begin{array}{l}\text { Closed-loop, Product Recovery } \\
\text { and Recycling }\end{array}$ & $\begin{array}{l}\text { Chung and Wee (2008), Defee et al. (2009), Quariguasi Frota Neto et al. (2010), Bing (2013), } \\
\text { Georgiadis and Vlachos (2004), Mangla et al. (2013), Abdallah et al. (2012), Gupta and Evans (2009), Ji } \\
\text { (2008), Kannan et al. (2010), Savaskan et al. (2004), Vlachos et al. (2007), Wang and Hsu (2010a, } \\
\text { 2010b), Beamon and Fernandes (2004) }\end{array}$ \\
\hline
\end{tabular}

Table V Papers categorised by academic subject, type of research and decision analysis type (in brackets)

\begin{tabular}{|c|c|c|c|}
\hline Academic subject & Type of research (and decision analysis) & $\begin{array}{c}\text { Number of } \\
\text { papers }\end{array}$ & $\%$ of total \\
\hline Operational Research & Normative (rational) & 97 & 60.25 \\
\hline Operational Research & Empirical (behavioural) & 0 & 0 \\
\hline Operational Research & General: litewrature review or conceptual & 3 & 1.88 \\
\hline Business Ethics & Normative (rational) & 7 & 4.38 \\
\hline Business Ethics & Empirical (behavioural) & 7 & 4.38 \\
\hline Business Ethics & General: literature review or conceptual & 4 & 2.50 \\
\hline Others (OM/SCM/SSCM) & Normative (rational) & 6 & 3.75 \\
\hline Others (OM/SCM/SSCM) & Empirical (behavioural) & 20 & 12.50 \\
\hline Others (OM/SCM/SSCM) & General: literature review or conceptual & 15 & 9.38 \\
\hline \multirow[t]{2}{*}{ Exceptions } & & 1 & 0.63 \\
\hline & Total & 160 & 100 \\
\hline
\end{tabular}

Of the 160 papers, some could be readily classified by title alone due to explicit mention of a familiar decision analysis method which clearly related to a specific decision context. Where this was not possible, papers were read in detail to enable classification.

The classification based on the Cynefin framework links the structural nature of the decision context to the type of decision-making method applied. This looks at the extent to which the decision context is structured or unstructured, is about bureaucratic process, complicated analysis, complex emergence or inherent unpredictability. These classifications are discussed in the following section.

As shown in Table VI, of 160 papers, exactly 100 are classified as concerning structured complicated decision contexts. Note that these are not the same 100 papers classified as OR in Table V. This category clearly dominates the research set. However, the unstructured complex domain is discussed in a small number of six papers in OR, and a further 4 four papers classed as Others, making 10 in total.

The structured simple domain includes papers that concern decisions relating to metrics and standards for SSCM. This includes zero papers from OR, no doubt because $\mathrm{OR}$ by definition is concerned with analysing complicated sets of variables, again, explaining the vast majority of papers being in the structured, complicated domain. A further nine papers in the structured, simple domain are classified in non-OR topics. 
Table VI Papers categorised by Cynefin typology

\begin{tabular}{|c|c|c|c|c|}
\hline Cynefin domain & $\begin{array}{l}\text { Snowden's } \\
\text { responses }\end{array}$ & Decision methods & Academic subject & Number of papers \\
\hline \multirow[t]{3}{*}{ Structured-complicated } & \multirow[t]{3}{*}{ Analyse } & \multirow[t]{3}{*}{ Expert analysis } & Operational Research & 91 \\
\hline & & & Business Ethics & 1 \\
\hline & & & Others-OM/SCM/SSCM & 8 \\
\hline \multirow[t]{3}{*}{ Unstructured-complex } & \multirow[t]{3}{*}{ Probe } & Including CAS, SSM and & Operational Research & 6 \\
\hline & & \multirow[t]{2}{*}{ Values-focussed DA } & Business Ethics & 0 \\
\hline & & & Others-OM/SCM/SSCM & 4 \\
\hline \multirow[t]{3}{*}{ Unstructured-chaotic } & \multirow[t]{3}{*}{ Act } & \multirow{3}{*}{$\begin{array}{l}\text { Heuristics (including Guiding principles, } \\
\text { values and technical standards) }\end{array}$} & Operational Research & 0 \\
\hline & & & Business Ethics & See discussion \\
\hline & & & Others-OM/SCM/SSCM & 2 \\
\hline \multirow[t]{3}{*}{ Structured-simple } & \multirow[t]{3}{*}{ Categorise } & \multirow[t]{3}{*}{ Procedural } & Operational Research & 0 \\
\hline & & & Business Ethics & 1 \\
\hline & & & Others-OM/SCM/SSCM & 8 \\
\hline \multirow{3}{*}{$\begin{array}{l}\text { Exceptions or unclassified } \\
\text { papers (See Section } 5 . \\
\text { Discussion) }\end{array}$} & & & Operational Research & 3 \\
\hline & & & Business Ethics & 16 \\
\hline & & & Others-OM/SCM/SSCM & 20 \\
\hline
\end{tabular}

Finally, there is the unstructured, chaotic domain. Here, no papers explicitly refer to this, but a number of empirical papers refer to means by which managers use simplification heuristics to deal with uncertainty (Pagell and Wu (2009); Wu and Pagell (2011)) or unmanageably large datasets (McIntyre et al., 1998; Kalleitner-Huber et al., 2012). These are means to move a decision context toward simplicity, which Snowden and Boone (2007) say is an action that may be taken in the chaotic domain. In contrast, one empirical paper in business ethics, (Kalshoven and Meijboom, 2013) examines eco-labelling in the fishing industry and finds it unable to assist in the complex decisions the sector faces. This suggests that the simple structured response of product labelling is an insufficient response. The paper concludes, "in order to move forward, the sector needs to further reflect and elaborate on its core values." This echoes the recommendations of Keeney (1996).

Values, mindset, organisational culture and orientations to stakeholders or investors are a common theme across a number of papers. These papers do not fit readily into the discussion of the Cynefin framework domains and so form part of the final set of papers in Table VI, which are those left unclassified. (An additional exception is a single paper, Hirsch and Meyer, 2010, that is clearly both OR and business ethics, which arguably belongs in the structured complicated set but is excluded due to its deliberately hybrid academic subject). Also, a like-for-like correlation with the Cynefin domains and value-focussed analysis is not possible. Whereas OR is centrally about attributes and as such is clearly identified within Cynefin's structured, complicated domain, value-focussed analysis is a potential means for addressing all forms of decision context, and as such does not reside within a single domain. Further discussion continues in the following section.

\section{Discussion of SSCM decision literature}

This discussion section briefly covers the four Cynefin domains and then Keeney's value-focussed decision analysis, before drawing concluding comments regarding theory building in SSCM.

\subsection{SSCM research dealing with structured decision contexts}

Papers in the structured simple domain include those addressing metrics, standards and regulations relating to SSCM. Examples include, Handfield et al. (2005) on integrating environmental management systems and metrics with purchasing decisions; Vasileiou and Morris (2006) exploring food sector sustainability, concluding there is a need for objective performance indicators; and Meul et al. (2009) on the validation of such indicators. Also, those dealing with simplification heuristics, notably McIntyre et al. (1998), on the environmental decision model developed at Xerox and Kalleitner-Huber et al. (2012) on assessing the product lines of a major retailer. Wu and Pagell (2011) describe these heuristics as "guiding principles" or "technical standards" which although not providing categorical prediction and proof, give enough of a guide to enable effective decision-making.

Outside of this systematic literature review, Hassini et al. (2012) record a vast number of metrics used for SSCM issues. These range from "volume of pollutant discharged to a water course" to "level of investment in community development projects". Alongside French and Geldermann (2005), which points to the prevalence of multiple variables in sustainability, this shows that simple bureaucratic responses are often insufficient. Instead, as discussed further in French et al. (2009) and French (2012), the different domains of the Cynefin framework show that different decision contexts need different decision methods.

Many papers found by this review address structured complicated problems using a wide range of OR methods. These range from OR applied to SSCM as a means to reduce waste, such as Everingham et al. (2008). Some add an environmental factor to a conventional quality, quantity or price model. Carbon dioxide is one such factor, not least, as it is a measure of pollution under increasing regulatory scrutiny (Chaabane et al., 2011; Choi, 2013; Harris et al., 2011; Jaegler and Burlat, 2012). Other regulatory factors include the European Union Waste Electrical and Electronic Equipment directive (Quariguasi Frota Neto et al., 2010). Aspects of supply chain structure are also discussed by using models to 
determine optimum outputs. For instance, Swami and Shah (2012) show optimum results from supply chain co-ordination and co-operation; Cruz and Wakolbinger (2008) compute optimum production outputs, given different levels of investment in CSR; Oglethorpe (2010) seek optimal outcome given different end results desired by multiple stakeholders.

The more variables needed, the more complicated the decision context is and so more sophisticated decision analysis process is required. Various SSCM papers using MCDA (Wang and Chan, 2013), MILP (Metta and Badurdeen, 2013; Ramezani et al., 2013) or ANP (Hsu and Hu, 2009; Sarkis, 1998; Zanoni and Zavanella, 2012; Zhu et al., 2010) point to this.

A number of OR papers use fuzzy logic, grey sets or stochastic modelling as mathematical means to address uncertainty. However, some of this serves to accommodate uncertainty within a structured model. It is not the same as addressing the unstructured complex domain approaches such as Complex Adaptive Systems, agent-based modelling and network analysis or unstructured interpretive approaches such as Soft Systems Methodology.

\subsection{Supply chain decisions in unstructured contexts}

Assuming that SSCM metrics are easily modelled and a regulatory bureaucracy can be enforced does not address the potential for unstructured decision contexts in SSCM. As noted in Sarkis (2003), establishing robust metrics and a realistic model can be prohibitively expensive, and thus may only apply to very large investment decision that warrant the effort. Similarly, products may change faster than the process of recording key attributes and then modelling them, rendering the process ineffective. One of the papers found by this review, Higgins et al. (2009), focuses on how OR techniques have failed when applied to sustainability and resilience of agricultural value chains. Farmers face inherent levels of unpredictability in their productivity as a result of dependence on the weather. Such factors are less common in the more controlled context of manufacturing where $\mathrm{OR}$ is more appropriate. Instead, Higgins proposes using the analytical methods of Complex Adaptive Systems theory. Other sectors significantly affected by weather include shipping and construction.

A small number of other papers addressing the unstructured complex domain in SSCM research include Halog and Manik (2011) using systems theory for stakeholder analysis and life cycle analysis, Giannakis and Louis (2011) using multi-agent modelling to mitigate risk, Fritz and Schiefer (2009) on deadlocks between firm level, sector level and policy level interests due to complexity, Vurro et al. (2009) on how centrality in a network influences collaboration, Tyler et al. (2006) on barriers to sustainability in textile and fashion sectors and Tavella and Hjortsø (2012) on Soft Systems Methodology in retail. Further relevant conceptual discussion is seen in Cohen and Kunreuther (2007), addressing the legacy of Paul Kleindorfer in environmental and risk management, and in Cabral et al. (2012), where balancing the needs of lean, agile, resilient and green in SCM is described as, "a complex problem, involving dependencies and feedbacks."

The unstructured, chaotic domain of the Cynefin framework is characterised by high levels of uncertainty and by significant, unpredictable change or disruption. This is clearly a topic of interest to SCM and SSCM and discussed in papers on supply chain risk and resilience, such as Harland et al. (2003) or Sheffi and Rice (2005). However, such papers do not address supply chain risk with reference to both decision-making and sustainability and so have not been included in this systematic review. Given the relative youth of SSCM as a research topic, although research has started to investigate the non-linear mathematics of chaos in SCM, such as Wang et al. (2012a), it has not yet been applied to SSCM and so is under-represented. Hence, the main way in which the unstructured, chaotic domain may be represented in SSCM research is in relation to simplification heuristics (Pagell and Wu, 2009; Wu and Pagell, 2011) which suggest the use of value-focussed decision analysis.

A further example of the significance of the unstructured domain is seen in Lawrence et al. (2002). This shows that improvements in environmental performance cannot be achieved unless the use of sustainability metrics in environmental decision-making are also integrated into strategic management decision-making. Under the perspective of the Cynefin framework, this means considering how structured, bureaucratic metrics for SSCM relate to the unstructured problem context of high-level corporate strategy.

As discussed in Snowden and Boone (2007), individual or organisational mindsets regarding each domain have a powerful influence, and this is reflected in organisational culture. Bureaucrats and bureaucratic organisations tend to approach decision problems from the perspective of the simple domain, professional analysts, including management consultants, approach problems from the perspective of the complicated domain. The complex domain is how practitioners of stakeholder engagement proceed, where consensus and dialogue is sought, respecting of individual points of view. Choi et al. (2001), apply this to SCM, surrendering the traditional mindset of a commandand-control supply chain and instead letting order emerge through mutual self-interest. Finally, the chaotic domain may be favoured by authoritarians as grounds for the imposition of order and control, bringing the context back into the structured and simple domain. The dynamic nature of these transitions and the link to cognition are detailed in Snowden (2002) and Snowden and Boone (2007). For SSCM, existing research is divided between that which assumes decision problems are structured (including the conventional OR, systems dynamics set) and that which assumes it is unstructured (including the Complex Adaptive Systems set). A further finding of the research that is uniquely relevant to the sustainability question is now described.

\subsection{Ethical decision-making research, values and SSCM}

As discussed by Tranfield et al. (2003), systematic literature review provides an opportunity for cross-disciplinary understanding, and the findings of this review support this. By searching for the word "decision" - albeit a basic and relatively unambiguous phrase in management literature - in the context ethics, CSR and SSCM, a small but significant set of papers has been included from the field of business ethics. This is a wholly different academic branch from OR but 
reflects the arguments of Keeney (1996) and so is directly associated with DT. These papers on ethical decision-making in supply chains do not, however, explicitly mention DT. Yet there is a clear opportunity for SSCM theory building through synthesising the ethical discourse with Keeney's value-focussed decision analysis. Also, whereas the OR papers are almost exclusively normative \& rational, the ethics papers are both normative and rational, and empirical and behavioural.

The earliest study discussing ethics in the context of supply chain management is Waters et al. (1986). At this time, CSR was not recorded as an ethical duty of companies. This notion appears in Haynes and Helms (1991) and then Plank et al. (1994), who show ethical behaviour in purchasing decisions is linked to organisational culture and overall business objectives. Organisational culture is also a key feature in Lawrence et al. (2002), Davies and Crane (2003), Lahdesmaki (2005) and Jiyun (2010). Each of these papers discuss biases in the ethical decision-making behaviour, in line with behavioural decision analysis. Benefits of alignment in ethical values between firms and their suppliers, customers or other stakeholders, is seen in Isern (2006) using the Value-Driven Management approach of Pohlman and Gardiner (2000) to examine child labour in cocoa production, Svensson and Bååth (2008) on ethical orientations in automotive and Reuter et al. (2012), on the effect of stakeholder-orientiation on supplier selection decisions.

The role of "stakeholder orientation" is a significant theme throughout these papers. Reuter et al. (2012) show that firms with a "public orientation" are less sensitive to cost as a variable in the selection decision than those that are "shareholder-oriented". Thus, a trade-off between cost and sustainability criteria in supplier selection is affected by the organisational culture. The orientation of the firm may also be directly affected by the nature of the ownership and investment status of the firm.

Businesses that centre on an ethical and/or sustainable proposition may be privately owned, and more sensitive to a value-focussed approach than a cost-sensitive alternatives focus. The values of the firm's owner may provide the overarching framework for decisions. If they are publicly listed and owned by shareholders, the ability to resist cost sensitivity may be dependent on the relationship between directors and shareholders. Tim Cook of Apple, Paul Polman of Unilever and the late Ray Anderson of InterfaceFLOR all offer examples of CEOs apparently in strong enough positions to put their values and vision ahead of short-term cost sensitivity. Isern (2006) details how cost sensitivity drives downward pressure on suppliers, and thereby prompts negative social or environmental impacts.

Although the majority of ethical papers are descriptive normative decision models include Fudge and Schlacter (1999), on developing a culture where employees consider moral issues, and Ferrell et al. (2013), taking a framework for ethics in marketing and adapting it to SCM. One example of "prescriptive" decision analysis is seen in Woiceshyn (2011), although this only makes passing reference to supply chain issues.

A further, significant paper provides a prescriptive decision model specifically for SSCM, built on both empirical research and normative theory and also bridges the business ethics and the OR camps. Hirsch and Meyer (2010) examines the need for a balance between co-operation between firms in a supply chain and the risk of opportunistic/exploitative behaviour by one of the parties. Reputation and ethical values are translated into economic language using a simple decision model based on game theory and transaction cost economics. The decision is then reframed as an investment problem. This allows for behavioural uncertainty to be addressed by judging the financial situation of the other party. The role of personal characteristics is also incorporated. This echoes work on the importance of ethical value alignment discussed previously, but notes there is an absence of work in the business ethics literature using the concepts of finance and accounting.

Hirsch and Meyer's influence for this approach is from the work of Homann and related scholars (Homann, 2008), translating economic statements into ethical statements and vice versa. This offers a new area for research considering sustainability criteria solely in terms of their ethical relevance, and hence their translation into economic rationale. Also, whereas OR researchers may seek more sophisticated modelling tools to bridge the two concepts of social sustainability and environmental sustainability, a more requisite approach may be to look to a more macro level where there is unity, namely, ethics.

\section{Conclusion: DT as a basis for research synthesis in SSCM}

This literature review has sought a systematic and interdisciplinary approach in tandem with the DT perspective of Simon (1960) and French et al. (2009), and the specific DT approaches of Keeney and Snowden. While the OR branch is an established sub-discipline of DT, and extensively used in SSCM, the business ethics branch is underdeveloped. Yet, the potential clearly exists for further development of SSCM theory. Prescriptive DT suggests addressing the rational calculation of likely outcomes in parallel with the behavioural and ethical considerations of what the implications of such an outcome may be.

The Cynefin framework gives awareness of how structured and unstructured circumstances affect the understanding of the decision-maker. Repeatedly, we see the interplay between these two. Managers call for SSCM to be translatable into simple and manageable metric models, while also acknowledging the uncertainty inherent in a rapidly changing and complex environment. More cutting-edge models in OR push against this complexity, finding ways to factor uncertainty into the modelling process. However, the approach to decision-making in the business ethics branch highlights the role of values and organisational culture.

These values can impose order on chaos or allow emergent order from complexity. Keeney's value-focussed approach to decision-making means setting a direction that goes beyond the constraining structure of existing mindsets and need for definable attributes for structured decision models. A normative outcome is a common feature in Sustainable Development, whether global carbon emissions or universal human rights. Moving toward a prescriptive decision analysis for SSCM reveals the importance of the political context of the decision-maker/s, the role of their personal values and the 
organisational culture in which they work. As shown by Gattiker and Carter (2010), leadership can be a highly significant enabler of SSCM. The extent to which a firm may demonstrate a mindset solely focussed on its own well-being, vs one that sees its well-being as linked to that of others may be a significant aspect of this. Stakeholder theory (Donaldson and Preston, 1995) provides one possible area for research synthesis alongside systems theory and sense-making, in line with the "public-orientation" of Reuter et al. (2012).

\section{Limitations and implications}

The first limitation of the research is that SSCM defines the boundary of the set. The 1,000 papers initially reviewed contained many that were excluded for not being primarily about SSCM. This excludes papers on SCM and decision-making (Figure 2, Section E), or sustainability and decision-making (Figure 2, Section F). Future research could study these for deeper insight into SSCM and DT. Papers from this group that show high relevance include Robertson and Crittenden (2003), Ojala and Hallikas (2006), Wasieleski and Weber (2008), Lozano and Huisingh (2011) and Webb (2012).

Greater research into behavioural decision-making and the overlap with ethical decision-making is needed. French et al. (2009) note that recent OR practice (such as "soft OR") is more nuanced to behavioural factors in decision-making, though this appears under-represented in the SSCM OR literature here. Operations Management, in contrast, has often considered both the rational analysis of process and production with the practical and psychological issues of implementation in the work place. Hence, OM is a natural platform from which to further develop DT as a basis for theory in SSCM.

The next phase in the research is for the authors to further examine the conceptual framework shown in Figure 4. This integrates the universal elements of rational normative DT with the contextual elements of behavioural empirical DT according to the prescriptive decision analysis approach (French et al., 2009). Managerial sense-making at Step 1 is central, and hence linking DT with SSCM prompts an exploration of how individual decision-maker cognition and alignment with organisational culture affects strategic and operational SSCM decision-making. The opportunity for management and civil society resulting from this application of DT to SSCM is that the various contested definitions or material relevance of sustainability to business may be understood with greater clarity. Implementing change can then benefit from this understanding.

Deeper understanding of the nature of decision-making offers a clear benefit to practice. As described by Snowden and Boone (2007), organisations and the people who work in them often have a tendency toward perceiving decisions in a certain way. Some tend to want to create bureaucratic processes, others seek careful analysis of options and a further group may dislike formal processes and stick to simple rules of thumb. All of this is highly relevant in the field of sustainability. First, because some managers may struggle with what sustainability means to them and their organisation. Competing definitions, global-scale problems, long timescales and potentially unclear paybacks can discourage managers who want simple, trustworthy advice. Second, because supplier relations may be vital for advancing corporate sustainability, the perspectives and values of other organisations have a key impact on how decisions are made and how well they are put into action. Third, the nature of policy as a driver of change, and whether a fundamentally bureaucratic process may or may not be key to meeting macro-scale environmental goals. Greater understanding of DT in relation to sustainable supply chain management, therefore, may benefit the practical delivery of sustainability objectives.

\section{References}

Abbasi, M. and Nilsson, F. (2012), "Themes and challenges in making supply chains environmentally sustainable", Supply Chain Management: An International fournal, Vol. 17 No. 5, pp. 517-530.

Abdallah, T., Diabat, A. and Simchi-Levi, D. (2012), "Sustainable supply chain design: a closed-loop formulation and sensitivity analysis", Production Planning and Control, Vol. 23 Nos 2/3, pp. 120-133.

Adhitya, A., Halim, I. and Srinivasan, R. (2011), "Decision support for green supply chain operations by integrating dynamic simulation and LCA indicators: diaper case study", Environmental Science and Technology, Vol. 45 No. 23, pp. 10178-10185.

Akkerman, R., Farahani, P. and Grunow, M. (2010), "Quality, safety and sustainability in food distribution: a review of quantitative operations management approaches and challenges", Or Spectrum, Vol. 32 No. 4, pp. 863-904.

Albino, V., Izzo, C. and Kühtz, S. (2002), "Input-output models for the analysis of a local/global supply chain", International Fournal of Production Economics, Vol. 78 No. 2, pp. 119-131.

Arimura, T.H., Darnall, N. and Katayama, H. (2011), "Is ISO 14001 a gateway to more advanced voluntary action? The case of green supply chain management", fournal of Environmental Economics and Management, Vol. 61 No. 2, pp. 170-182.

Bai, C. and Sarkis, J. (2010a), "Green supplier development: analytical evaluation using rough set theory", fournal of Cleaner Production, Vol. 18 No. 12, pp. 1200-1210.

Bai, C. and Sarkis, J. (2010b), "Integrating sustainability into supplier selection with grey system and rough set methodologies", International fournal of Production Economics, Vol. 124 No. 1, pp. 252-264.

Bai, C., Sarkis, J. and Wei, X. (2010), "Addressing key sustainable supply chain management issues using rough set methodology", Management Research Review, Vol. 33 No. 12, pp. 1113-1127.

Beamon, B.M. and Fernandes, C. (2004), "Supply-chain network configuration for product recovery", Production Planning and Control, Vol. 15 No. 3, pp. 270-281.

Bellamy, M.A. and Basole, R.C. (2013), "Network analysis of supply chain systems: a systematic review and future research", Systems Engineering, Vol. 16 No. 2, pp. 235-249.

Bing, X. (2013), "Multimodal network design for sustainable household plastic recycling", International fournal of Physical Distribution and Logistics Management, Vol. 43 Nos 5/6, pp. 452-477. 
Björklund, M. (2010), "Linking strategic logistics change to labor rights", Social Responsibility fournal, Vol. 6 No. 4, pp. 580-592.

Bloemhof-Ruwaard, J.M., Van Beek, P., Hordijk, L. and Van Wassenhove, L.N. (1995), "Interactions between operational research and environmental management", European fournal of Operational Research, Vol. 85 No. 2, pp. 229-243.

Bockholt, F., Raabe, W. and Toth, M. (2011), "Logistic assistance systems for collaborative supply chain planning", International fournal of Simulation and Process Modelling, Vol. 6 No. 4, pp. 297-307.

Bouchery, Y., Ghaffari, A., Jemai, Z. and Dallery, Y. (2012), "Including sustainability criteria into inventory models", European fournal of Operational Research, Vol. 222 No. 2, pp. 229-240.

Breite, R. and Koskinen, K.U. (2014), "Supply chain as an autopoietic learning system", Supply Chain Management: An International fournal, Vol. 19 No. 1, pp. 10-16.

Brundtland, G.H. (1987), Our Common Future, United Nations, New York, NY.

Büyüközkan, G. and Çifçi, G. (2011), "A novel fuzzy multi-criteria decision framework for sustainable supplier selection with incomplete information", Computers in Industry, Vol. 62 No. 2, pp. 164-174.

Büyüközkan, G. and Çifçi, G. (2012), "Evaluation of the green supply chain management practices: a fuzzy ANP approach", Production Planning and Control, Vol. 23 No. 6, pp. 405-418.

Cabral, I., Grilo, A. and Cruz-Machado, V. (2012), “A decision-making model for Lean, Agile, Resilient and Green supply chain management", International fournal of Production Research, Vol. 50 No. 17, pp. 4830-4845.

Carter, C.R. and Rogers, D.S. (2008), "A framework of sustainable supply chain management: moving toward new theory", International fournal of Physical Distribution and Logistics Management, Vol. 38 No. 5, pp. 360-387.

Chaabane, A., Ramudhin, A. and Paquet, M. (2011), "Designing supply chains with sustainability considerations", Production Planning and Control, Vol. 22 No. 8, pp. 727-741.

Chaabane, A., Ramudhin, A. and Paquet, M. (2012), "Design of sustainable supply chains under the emission trading scheme", International fournal of Production Economics, Vol. 135 No. 1, pp. 37-49.

Che, Z.H., Chiang, T.A., Tu, C. and Chiang, C.-J. (2010), "A supplier selection model for product design changes", International fournal of Electronic Business Management, Vol. 8 No. 1, pp. 20-30.

Checkland, P. (1972), "Towards a systems-based methodology for real-world problem solving”, fournal of Systems Engineering, Vol. 3 No. 2, pp. 87-116.

Checkland, P. (1983), "O. R. and the systems movement: mappings and conflicts", fournal of the Operational Research Society, Vol. 34 No. 8, pp. 661-675.

Chicksand, D., Watson, G., Walker, H., Radnor, Z. and Johnston, R. (2012), "Theoretical perspectives in purchasing and supply chain management: an analysis of the literature", Supply Chain Management: An International fournal, Vol. 17 No. 4, pp. 454-472.
Choi, T.M. (2013), “Optimal apparel supplier selection with forecast updates under carbon emission taxation scheme", Computers and Operations Research, Vol. 40 No. 11, pp. 2646-2655.

Choi, T.M. and Chiu, C.-H. (2012), "Mean-downside-risk and mean-variance newsvendor models: implications for sustainable fashion retailing", International fournal of Production Economics, Vol. 135 No. 2, pp. 552-560.

Choi, T.Y., Dooley, K.J. and Rungtusanatham, M. (2001), "Supply networks and complex adaptive systems: control versus emergence", fournal of Operations Management, Vol. 19 No. 3, pp. 351-366.

Chung, C.J. and Wee, H.-M. (2008), "Green-component life-cycle value on design and reverse manufacturing in semi-closed supply chain", International fournal of Production Economics, Vol. 113 No. 2, pp. 528-545.

Chung, C.J. and Wee, H.-M. (2011), "Short life-cycle deteriorating product remanufacturing in a green supply chain inventory control system", International fournal of Production Economics, Vol. 129 No. 1, pp. 195-203.

Cohen, M.A. and Kunreuther, H. (2007), "Operations risk management: overview of Paul Kleindorfer's contributions", Production and Operations Management, Vol. 16 No. 5, pp. 525-541.

Cruz, J. (2009), "The impact of corporate social responsibility in supply chain management: multicriteria decision-making approach", Decision Support Systems, Vol. 48 No. 1, pp. 224-236.

Cruz, J.M. (2013), "Mitigating global supply chain risks through corporate social responsibility", International Fournal of Production Research, Vol. 51 No. 13, pp. 3995-4010.

Cruz, J.M. and Wakolbinger, T. (2008), "Multiperiod effects of corporate social responsibility on supply chain networks, transaction costs, emissions, and risk", International fournal of Production Economics, Vol. 116 No. 1, pp. 61-74.

Dai, J. and Blackhurst, J. (2012), "A four-phase AHP-QFD approach for supplier assessment: a sustainability perspective", International fournal of Production Research, Vol. 50 No. 19, pp. 5474-5490.

Davies, I.A. and Crane, A. (2003), "Ethical decision making in fair trade companies", fournal of Business Ethics, Vol. 45 Nos $1 / 2$, pp. 79-92.

De Rosa, V., Gebhard, M., Hartmann, E. and Wollenweber, J. (2013), "Robust sustainable bi-directional logistics network design under uncertainty", International fournal of Production Economics, Vol. 145 No. 1, pp. 184-198.

Defee, C.C., Esper, T. and Mollenkopf, D. (2009), "Leveraging closed-loop orientation and leadership for environmental sustainability", Supply Chain Management: An International fournal, Vol. 14 No. 2, pp. 87-98.

Dekker, R., Bloemhof, J. and Mallidis, I. (2012), "Operations research for green logistics - an overview of aspects, issues, contributions and challenge", European fournal of Operational Research, Vol. 219 No. 3, pp. 671-679.

Denyer, D., Tranfield, D. and Van Aken, J.E. (2008), "Developing design propositions through research synthesis”, Organization Studies, Vol. 29 No. 3, pp. 393-413. 
Donaldson, T. and Preston, L.E. (1995), "The stakeholder theory of the corporation: concepts, evidence, and implications", Academy of Management Review, Vol. 20 No. 1, pp. 65-91.

Dubois, A. and Gadde, L.E. (2002), "Systematic combining: an abductive approach to case research", Fournal of Business Research, Vol. 55 No. 7, pp. 553-560.

Dubois, A. and Gibbert, M. (2010), "From complexity to transparency: managing the interplay between theory, method and empirical phenomena in IMM case studies", Industrial Marketing Management, Vol. 39 No. 1, pp. 129-136.

Early, C., Kidman, T., Menvielle, M., Geyer, R. and McMullan, R. (2009), "Informing packaging design decisions at Toyota motor sales using life cycle assessment and costing", fournal of Industrial Ecology, Vol. 13 No. 4, pp. 592-606.

Efendigil, T., Önüt, S. and Kongar, E. (2008), “A holistic approach for selecting a third-party reverse logistics provider in the presence of vagueness", Computers and Industrial Engineering, Vol. 54 No. 2, pp. 269-287.

El Saadany, A., Jaber, M. and Bonney, M. (2011), "Environmental performance measures for supply chains", Management Research Review, Vol. 34 No. 11, pp. 1202-1221.

Eskandarpour, M., Zegordi, S.H. and Nikbakhsh, E. (2013), "A parallel variable neighborhood search for the multi-objective sustainable post-sales network design problem", International fournal of Production Economics, Vol. 145 No. 1, pp. 117-131.

Everingham, K., Polaski, G., Riedlin, F., Shirk, M., Deshpande, V. and Iyer, A.V. (2008), “Operations research enhances supply chain management at the US coast guard aircraft repair and supply center", Interfaces, Vol. 38 No. 1, pp. 61-75.

Fava, J., Baer, S. and Cooper, J. (2009), "Increasing demands for life cycle assessments in North America", fournal of Industrial Ecology, Vol. 13 No. 4, pp. 491-494.

Ferrell, O., Rogers, M.M., Ferrell, L. and Sawayda, J. (2013), "a framework for understanding ethical supply chain decision making”, fournal of Marketing Channels, Vol. 20 Nos 3/4, pp. 260-287.

French, S. (2012), "Cynefin, statistics and decision analysis", Fournal of the Operational Research Society, Vol. 64 No. 4, pp. 547-561.

French, S. and Geldermann, J. (2005), "The varied contexts of environmental decision problems and their implications for decision support", Environmental Science and Policy, Vol. 8 No. 4, pp. 378-391.

French, S., Maule, J. and Papamichail, N. (2009), Decision Behaviour, Analysis and Support, Cambridge University Press, Cambridge.

Fritz, M. and Schiefer, G. (2009), "Tracking, tracing, and business process interests in food commodities: a multi-level decision complexity", International fournal of Production Economics, Vol. 117 No. 2, pp. 317-329.

Fudge, R.S. and Schlacter, J.L. (1999), "Motivating employees to act ethically: an expectancy theory approach", Fournal of Business Ethics, Vol. 18 No. 3, pp. 295-304.
Gattiker, T.F. and Carter, C.R. (2010), "Understanding project champions' ability to gain intra-organizational commitment for environmental projects", fournal of Operations Management, Vol. 28 No. 1, pp. 72-85.

Georgiadis, P. and Vlachos, D. (2004), "The effect of environmental parameters on product recovery", European Fournal of Operational Research, Vol. 157 No. 2, pp. 449-464.

Ghosh, D. and Shah, J. (2012), "A comparative analysis of greening policies across supply chain structures", International Fournal of Production Economics, Vol. 135 No. 2, pp. 568-583.

Giannakis, M. and Louis, M. (2011), "A multi-agent based framework for supply chain risk management", fournal of Purchasing and Supply Management, Vol. 17 No. 1, pp. 23-31.

Gimenez, C. and Tachizawa, E.M. (2012), "Extending sustainability to suppliers: a systematic literature review", Supply Chain Management: An International fournal, Vol. 17 No. 5, pp. 531-543.

Gimenez, C., Sierra, V., and Rodon, J. (2012), "Sustainable operations: their impact on the triple bottom line", International fournal of Production Economics, Vol. 140 No. 1, pp. 149-159.

Gupta, A. and Evans, G.W. (2009), "A goal programming model for the operation of closed-loop supply chains", Engineering optimization, Vol. 41 No. 8, pp. 713-735.

Haanaes, K., Balagopal, B., Kong, M.T., Velken, I., Arthur, D., Hopkins, M.S. and Kruschwitz, N. (2011), “The'Embracers' seize advantage”, MIT Sloan Management Review, Vol. 52 No. 3, p. 23.

Halog, A. and Manik, Y. (2011), "Advancing integrated systems modelling framework for life cycle sustainability assessment”, Sustainability, Vol. 3 No. 2, pp. 469-499.

Handfield, R., Sroufe, R. and Walton, S. (2005), "Integrating environmental management and supply chain strategies", Business Strategy and the Environment, Vol. 14 No. 1, pp. 1-19.

Harland, C., Brenchley, R. and Walker, H. (2003), "Risk in supply networks", Fournal of Purchasing and Supply Management, Vol. 9 No. 2, pp. 51-62.

Harris, I., Naim, M., Palmer, A., Potter, A. and Mumford, C. (2011), "Assessing the impact of cost optimization based on infrastructure modelling on CO2 emissions", International Fournal of Production Economics, Vol. 131 No. 1, pp. 313-321.

Harvey, C., Kelly, A., Morris, H. and Rowlinson, M. (2011), ABS fournal Quality Guide, The Association of Business Schools, London.

Hassini, E., Surti, C. and Searcy, C. (2012), "A literature review and a case study of sustainable supply chains with a focus on metrics", International fournal of Production Economics, Vol. 140 No. 1, pp. 69-82.

Haynes, P.J. and Helms, M.M. (1991), "An ethical framework for purchasing decisions", Management Decision, Vol. 29 No. 1.

Higgins, A.J., Miller, C.J., Archer, A.A., Ton, T., Fletcher, C.S. and McAllister, R.R.J. (2009), "Challenges of operations research practice in agricultural value chains", 
Fournal of the Operational Research Society, Vol. 61 No. 6, pp. 964-973.

Hirsch, B. and Meyer, M. (2010), "Integrating soft factors into the assessment of cooperative relationships between firms: accounting for reputation and ethical values", Business Ethics: A European Review, Vol. 19 No. 1, pp. 81-94.

Homann, K. (2008), "Profit and morality in global responsibility", in Luetge, C., Schönwälder-Kuntze, T. and Conill, J. (Eds), Corporate Citizenship, Contractarianism and Ethical Theory: Philosophical Considerations of Business Ethics, Ashgate, Farnham, pp. 79-86.

Hsu, C.W. and $\mathrm{Hu}$, A.H. (2009), "Applying hazardous substance management to supplier selection using analytic network process", fournal of Cleaner Production, Vol. 17 No. 2, pp. 255-264.

$\mathrm{Hu}$, G. and Bidanda, B. (2009), "Modeling sustainable product lifecycle decision support systems", International fournal of Production Economics, Vol. 122 No. 1, pp. 366-375.

Hutchins, M.J. and Sutherland, J.W. (2008), “An exploration of measures of social sustainability and their application to supply chain decisions", Fournal of Cleaner Production, Vol. 16 No. 15, pp. 1688-1698.

Isern, J. (2006), "Bittersweet chocolate: the legality and ethics of child labor in cocoa production in Côte d'Ivoire", fournal of Applied Management and Entrepreneurship, Vol. 11 No. 1, pp. 115-132.

Jaegler, A. and Burlat, P. (2012), "Carbon friendly supply chains: a simulation study of different scenarios", Production Planning and Control, Vol. 23 No. 4, pp. 269-278.

Jaques, E. (1989), Requisite Organization: The CEO's Guide to Creative Structure and Leadership, Cason Hall \& Co. Publishers, Falls Church, USA.

Ji, G. (2008), "Performance evaluation of complaint management and virtual enterprise in closed-loop supply chains by using exergoeconomics and extenics", International fournal of Services and Operations Management, Vol. 4 No. 3, pp. 368-397.

Jiyun, W. (2010), “The impact of corporate supplier diversity programs on corporate purchasers' intention to purchase from women-owned enterprises: an empirical test", Business and Society, Vol. 49 No. 2, pp. 359-380.

Kalleitner-Huber, M., Schweighofer, M. and Sieber, W. (2012), "How to shift 100,000 products toward sustainability: creating a sustainable assortment at Haberkorn", Clean Technologies and Environmental Policy, Vol. 14 No. 6, pp. 1059-1064.

Kalshoven, K. and Meijboom, F.L. (2013), "Sustainability at the crossroads of fish consumption and production ethical dilemmas of fish buyers at retail organizations in The Netherlands", Fournal of Agricultural and Environmental Ethics, Vol. 26 No. 1, pp. 101-117.

Kannan, D., Khodaverdi, R., Olfat, L., Jafarian, A. and Diabat, A. (2013), "Integrated fuzzy multi criteria decision making method and multi-objective programming approach for supplier selection and order allocation in a green supply chain", fournal of Cleaner Production, Vol. 43, pp. 355-367.

Kannan, G., Haq, A.N., Sasikumar, P. and Arunachalam, S. (2008), "Analysis and selection of green suppliers using interpretative structural modelling and analytic hierarchy process", International Fournal of Management and Decision Making, Vol. 9 No. 2, pp. 163-182.

Kannan, G., Murugesan, P., Senthil, P. and Noorul Haq, A. (2009), "Multicriteria group decision making for the third party reverse logistics service provider in the supply chain model using fuzzy TOPSIS for transportation services", International Fournal of Services Technology and Management, Vol. 11 No. 2, pp. 162-181.

Kannan, G., Sasikumar, P. and Devika, K. (2010), “A genetic algorithm approach for solving a closed loop supply chain model: a case of battery recycling", Applied Mathematical Modelling, Vol. 34 No. 3, pp. 655-670.

Keeney, R. (1996), "Value-focussed thinking: identifying decision opportunities and creating alternatives", European Fournal of Operational Research, Vol. 92 No. 3, pp. 537-549.

Keeney, R. and Gregory, R.S. (2005), "Setting attributes to measure the achievement of objectives", Operations Research, Vol. 53 No. 1, pp. 1-11.

Khoo, H.H., Spedding, T.A., Bainbridge, I. and Taplin, D.M. (2001), "Creating a green supply chain", Greener Management International, Vol. 2001 No. 35, pp. 70-88.

Kovács, G. and Spens, K.M. (2005), "Abductive reasoning in logistics research", International Fournal of Physical Distribution and Logistics Management, Vol. 35 No. 2, pp. 132-144.

Kuo, R., Wang, Y. and Tien, F. (2010), "Integration of artificial neural network and MADA methods for green supplier selection", fournal of Cleaner Production, Vol. 18 No. 12, pp. 1161-1170.

Kurtz, C.F. and Snowden, D.J. (2003), "The new dynamics of strategy: sense-making in a complex and complicated world", IBM Systems fournal, Vol. 42 No. 3, pp. 462-483.

Lahdesmaki, M. (2005), "When ethics matters - interpreting the ethical discourse of small nature-based entrepreneurs", Fournal of Business Ethics, Vol. 61 No. 1, pp. 55-68.

Lamming, R. and Hampson, J. (1996), "The environment as a supply chain management issue", British fournal of Management, Vol. 7 No. S1, pp. S45-S62.

Lawrence, E., Andrews, D., Ralph, B. and France, C. (2002), "Applying organizational environmental tools and techniques", Corporate Social Responsibility and Environmental Management, Vol. 9 No. 2, pp. 116-125.

Lee, C.W. (2008), "Green suppliers with environmental performance in the supply chain perspective", Asia Pacific Management Review, Vol. 13 No. 4, pp. 731-745.

Lenzen, M. (2008), "Double-counting in life cycle calculations", Fournal of Industrial Ecology, Vol. 12 No. 4, pp. 583-599.

Lepineux, F. (2005), "Stakeholder theory, society and social cohesion", Corporate Governance, Vol. 5 No. 2, pp. 99-110.

Liao, S.S. (2013), "Enhancing ethics and the competitive environment by accounting for conflict of interest in project procurement", Leadership and Management in Engineering, Vol. 13 No. 2, pp. 86-95.

Littig, B. and Griessler, E. (2005), "Social sustainability: a catchword between political pragmatism and social theory", International fournal of Sustainable Development, Vol. 8 No. 1, pp. 65-79. 
Lozano, R. and Huisingh, D. (2011), "Inter-linking issues and dimensions in sustainability reporting", Fournal of Cleaner Production, Vol. 19 No. 2, pp. 99-107.

Lu, L.Y., Wu, C. and Kuo, T.-C. (2007), "Environmental principles applicable to green supplier evaluation by using multi-objective decision analysis", International fournal of Production Research, Vol. 45 Nos 18/19, pp. 4317-4331.

McIntyre, K., Smith, H., Henham, A. and Pretlove, J. (1998), "Environmental performance indicators for integrated supply chains: the case of Xerox Ltd", Supply Chain Management: An International fournal, Vol. 3 No. 3, pp. 149-156.

Mackenzie, A., Pidd, M., Rooksby, J., Sommerville, I., Warren, I. and Westcombe, M. (2006), "Wisdom, decision support and paradigms of decision making", European Fournal of Operational Research, Vol. 170 No. 1, pp. 156-171.

Mangla, S., Madaan, J. and Chan, F.T. (2013), "Analysis of flexible decision strategies for sustainability-focused green product recovery system", International Fournal of Production Research, Vol. 51 No. 11, pp. 3428-3442.

Merrick, R.J. and Bookbinder, J.H. (2010), "Environmental assessment of shipment release policies", International Fournal of Physical Distribution and Logistics Management, Vol. 40 No. 10, pp. 748-762.

Metta, H. and Badurdeen, F. (2013), "Integrating Sustainable product and supply chain design: modeling issues and challenges", IEEE Transactions on Engineering Management, Vol. 60 No. 2, pp. 438-446.

Meul, M., Nevens, F. and Reheul, D. (2009), "Validating sustainability indicators: focus on ecological aspects of Flemish dairy farms", Ecological Indicators, Vol. 9 No. 2, pp. 284-295.

Mintzberg, H. (1972a), "The myths of MIS", California Management Review, Vol. 15 No. 1, p. 92.

Mintzberg, H. (1972b), "Research on strategy-making", paper presented at the Academy of Management Proceedings.

Mitchell, R.K., Agle, B.R. and Wood, D.J. (1997), “Toward a theory of stakeholder identification and salience: defining the principle of who or what really counts", Academy of Management Review, Vol. 22 No. 4, pp. 853-886.

Muñoz, E., Capón-García, E., Laínez, J.M., Espuña, A. and Puigjaner, L. (2013), “Considering environmental assessment in an ontological framework for enterprise sustainability", Fournal of Cleaner Production, Vol. 47, pp. 149-164.

Nelson, D.M., Vonderembse, M.A. and Rao, S.S. (2011), "Life cycle evaluation strategies of biodiesel fuel along the supply chain in public transport", International fournal of Logistics Systems and Management, Vol. 9 No. 2, pp. 186-203.

Oglethorpe, D. (2010), "Optimising economic, environmental, and social objectives: a goal-programming approach in the food sector", Environment and Planning A, Vol. 42 No. 5, pp. 1239-1254.

Ojala, M. and Hallikas, J. (2006), "Investment decision-making in supplier networks: management of risk", International fournal of Production Economics, Vol. 104 No. 1, pp. 201-213.
Pagell, M. and Shevchenko, A. (2013), "Why research in sustainable supply chain management should have no future", fournal of Supply Chain Management, Vol. 50 No. 1.

Pagell, M. and Wu, Z. (2009), "Building a more complete theory of sustainable supply chain management using case studies of 10 exemplars", fournal of Supply Chain Management, Vol. 45 No. 2, pp. 37-56.

Pathak, S.D., Wu, Z. and Johnston, D. (2014), "Towards a structural view of co-opetition in supply networks", fournal of Operations Management, Vol. 32 No. 5, pp. 254-267.

Pidd, M. (1999), "Just modeling through: a rough guide to modeling”, Interfaces, Vol. 29 No. 2, pp. 118-132.

Plank, R.E., Landeros, R. and Plank, L.F. (1994), "Values driving decisions in questionable purchasing situations", International fournal of Purchasing and Materials Management, Vol. 30 No. 4, pp. 44-53.

Pohlman, R.A. and Gardiner, G.S. (2000), Value Driven Management: How to Create and Maximize Value Over Time for Organizational Success, AMACOM, New York, NY.

Poret, S. and Chambolle, C. (2007), "Fair trade labeling: inside or outside supermarkets?", Fournal of Agricultural and Food Industrial Organization, Vol. 5 No. 1, pp. 1-24.

Porter, M. (1985), Competitive Advantage: Creating and Sustaining Superior Performance, Free press, New York, NY.

Quariguasi Frota Neto, J., Walther, G., Bloemhof, J., van Nunen, J.A.E.E. and Spengler, T. (2010), "From closed-loop to sustainable supply chains: the WEEE case", International Fournal of Production Research, Vol. 48 No. 15, pp. 4463-4481.

Ramezani, M., Bashiri, M. and Tavakkoli-Moghaddam, R. (2013), “A new multi-objective stochastic model for a forward/reverse logistic network design with responsiveness and quality level", Applied Mathematical Modelling, Vol. 37 No. 1, pp. 328-344.

Reuter, C., Goebel, P. and Foerstl, K. (2012), "The impact of stakeholder orientation on sustainability and cost prevalence in supplier selection decisions", fournal of Purchasing and Supply Management, Vol. 18 No. 4, pp. 270-281.

Rittel, H.W. and Webber, M.M. (1973), "Dilemmas in a general theory of planning", Policy Sciences, Vol. 4 No. 2, pp. 155-169.

Robertson, C.J. and Crittenden, W.F. (2003), "Mapping moral philosophies: strategic implications for multinational firms", Strategic Management fournal, Vol. 24 No. 4, pp. 385-392.

Robinson, A.N. (2012), "Beyond sustainability: environmental management for the Anthropocene Epoch", Fournal of Public Affairs, Vol. 12 No. 3, pp. 184-194.

Sarkis, J. (1998), "Evaluating environmentally conscious business practices", European fournal of Operational Research, Vol. 107 No. 1, pp. 159-174.

Sarkis, J. (2003), "A strategic decision framework for green supply chain management", fournal of Cleaner Production, Vol. 11 No. 4, pp. 397-409.

Sarkis, J., Meade, L.M. and Presley, A.R. (2012), "Incorporating sustainability into contractor evaluation and team formation in the built environment", fournal of Cleaner Production, Vol. 31, pp. 40-53. 
Savaskan, R.C., Bhattacharya, S. and Van Wassenhove, L.N. (2004), "Closed-loop supply chain models with product remanufacturing", Management Science, Vol. 50 No. 2, pp. 239-252.

Seuring, S. (2013), "A review of modeling approaches for sustainable supply chain management", Decision Support Systems, Vol. 54 No. 4, pp. 1513-1520.

Sheffi, Y. and Rice, J. (2005), "A supply chain view of the resilient enterprise", MIT Sloan Management Review, Vol. 47 No. 1.

Simon, H.A. (1960), The New Science of Management Decision, Harper and Row, New York, NY.

Snowden, D. (2002), "Complex acts of knowing: paradox and descriptive self-awareness", fournal of Knowledge Management, Vol. 6 No. 2, pp. 100-111.

Snowden, D. and Boone, M. (2007), “A leader's framework for decision making", Harvard Business Review, November.

Statman, M. and Caldwell, D. (1987), "Applying behavioral finance to capital budgeting: project terminations", Financial Management, Vol. 16 No. 4, pp. 7-15.

Svensson, G. and Bååth, H. (2008), "Supply chain management ethics: conceptual framework and illustration", Supply Chain Management: An International Fournal, Vol. 13 No. 6, pp. 398-405.

Swami, S. and Shah, J. (2012), "Channel coordination in green supply chain management", fournal of the Operational Research Society, Vol. 64 No. 3, pp. 336-351.

Tachizawa, E.M., Thomsen, C.G. and Montes-Sancho, M.J. (2012), "Green supply management strategies in Spanish firms", IEEE Transactions on Engineering Management, Vol. 59 No. 4, pp. 741-752.

Tavella, E. and Hjortsø, C.N.P. (2012), "Enhancing the design and management of a local organic food supply chain with soft systems methodology", International Food and Agribusiness Management Review, Vol. 15 No. 2, pp. 47-68.

Tett, G. (2009), Fool's Gold: How the Bold Dream of a Small Tribe at FP Morgan was Corrupted by Wall Street Greed and Unleashed a Catastrophe, Simon and Schuster, New York, NY.

Toktay, L.B. and Wei, D. (2011), "Cost allocation in manufacturing-remanufacturing operations”, Production and Operations Management, Vol. 20 No. 6, pp. 841-847.

Tranfield, D., Denyer, D. and Smart, P. (2003), "Towards a methodology for developing evidence-informed management knowledge by means of systematic review", British Fournal of Management, Vol. 14 No. 3, pp. 207-222.

Tsai, W.H. and Hung, S.J. (2009), “A fuzzy goal programming approach for green supply chain optimisation under activity-based costing and performance evaluation with a value-chain structure", International fournal of Production Research, Vol. 47 No. 18, pp. 4991-5017.

Tseng, M.L. and Geng, Y. (2012), "Evaluating the green supply chain management using life cycle assessment approach in uncertainty", WSEAS Transactions on Environment and Development, Vol. 8 No. 4, pp. 133-157.

Tyler, D., Heeley, J. and Bhamra, T. (2006), "Supply chain influences on new product development in fashion clothing", fournal of Fashion Marketing and Management, Vol. 10 No. 3, pp. 316-328. van der Vorst, J., Tromp, S.O. and Zee, D.J. (2009), "Simulation modelling for food supply chain redesign; integrated decision making on product quality, sustainability and logistics", International fournal of Production Research, Vol. 47 No. 23, pp. 6611-6631.

Vasileiou, K. and Morris, J. (2006), "The sustainability of the supply chain for fresh potatoes in Britain", Supply Chain Management: An International fournal, Vol. 11 No. 4, pp. 317-327.

Vlachos, D., Georgiadis, P. and Iakovou, E. (2007), "A system dynamics model for dynamic capacity planning of remanufacturing in closed-loop supply chains", Computers and Operations Research, Vol. 34 No. 2, pp. 367-394.

Vurro, C., Russo, A. and Perrini, F. (2009), "Shaping sustainable value chains: network determinants of supply chain governance models", Fournal of Business Ethics, Vol. 90 No. 4, pp. 607-621.

Wang, F., Lai, X. and Shi, N. (2011), "A multi-objective optimization for green supply chain network design", Decision Support Systems, Vol. 51 No. 2, pp. 262-269.

Wang, H. and Hsu, H.W. (2010a), "A closed-loop logistic model with a spanning-tree based genetic algorithm", Computers and Operations Research, Vol. 37 No. 2, pp. 376-389.

Wang, H. and Hsu, H. (2010b), "Resolution of an uncertain closed-loop logistics model: an application to fuzzy linear programs with risk analysis", fournal of Environmental Management, Vol. 91 No. 11, pp. 2148-2162.

Wang, X. and Chan, H.K. (2013), "A hierarchical fuzzy TOPSIS approach to assess improvement areas when implementing green supply chain initiatives", International Fournal of Production Research, Vol. 51 No. 10, pp. 3117-3130.

Wang, X., Chan, H.K., Yee, R.W.Y. and Diaz-Rainey, I. (2012a), "A two-stage fuzzy-AHP model for risk assessment of implementing green initiatives in the fashion supply chain", International fournal of Production Economics, Vol. 135 No. 2, pp. 595-606.

Wang, X., Disney, S.M. and Wang, J. (2012b), "Stability analysis of constrained inventory systems with transportation delay", European fournal of Operational Research, Vol. 223 No. 1, pp. 86-95.

Wang, Y., Zhu, X., Lu, T. and Jeeva, A.S. (2013), "Eco-efficient based logistics network design in hybrid manufacturing/remanufacturing system in low-carbon economy", Fournal of Industrial Engineering and Management, Vol. 6 No. 1, pp. 200-214.

Wasieleski, D.M. and Weber, J. (2008), "Does job function influence ethical reasoning? An adapted Wason task application", Fournal of Business Ethics, Vol. 85 No. S1, pp. 187-199.

Waters, J.A., Bird, F. and Chant, P.D. (1986), "Everyday moral issues experienced by managers", Fournal of Business Ethics, Vol. 5 No. 5, pp. 373-384.

Webb, K. (2012), "Political risk insurance, CSR and the mining sector: an illustration of the regulatory effects of contracts", International fournal of Law and Management, Vol. 54 No. 5, pp. 394-415.

Wen, L., Xu, L. and Wang, R. (2013), "Sustainable supplier evaluation based on intuitionistic fuzzy sets group decision 
methods", fournal of Information and Computational Science, Vol. 10 No. 10, pp. 55-58.

Whiteman, G., Walker, B. and Perego, P. (2012), "Planetary boundaries: ecological foundations for corporate sustainability", Fournal of Management Studies, Vol. 50 No. 2, pp. 307-336.

Wittstruck, D. and Teuteberg, F. (2012), "Integrating the concept of sustainability into the partner selection process: a fuzzy-AHP-TOPSIS approach", International fournal of Logistics Systems and Management, Vol. 12 No. 2, pp. 195-226.

Woiceshyn, J. (2011), “A model for ethical decision making in business: reasoning, intuition, and rational moral principles", fournal of Business Ethics, Vol. 104 No. 3, pp. 311-323.

Wolf, C. and Seuring, S. (2010), "Environmental impacts as buying criteria for third party logistical services", International Fournal of Physical Distribution and Logistics Management, Vol. 40 Nos 1/2, pp. 84-102.

Wong, C.Y. and Acur, N. (2010), "Understanding inter-organizational decision coordination", Supply Chain Management: An International fournal, Vol. 15 No. 4, pp. 332-343.

Wu, J. (2010), “The impact of corporate supplier diversity programs on corporate purchasers' Intention to purchase from women-owned enterprises an empirical test", Business and Society, Vol. 49 No. 2, pp. 359-380.

Wu, Z. and Pagell, M. (2011), "Balancing priorities: decision-making in sustainable supply chain management", Fournal of Operations Management, Vol. 29 No. 6, pp. 577-590.

Xiao, R., Cai, Z. and Zhang, X. (2012), "An optimization approach to risk decision-making of closed-loop logistics based on SCOR model", Optimization, Vol. 61 No. 10, pp. 1221-1251.
Zanoni, S. and Zavanella, L. (2012), "Chilled or frozen? Decision strategies for sustainable food supply chains", International fournal of Production Economics, Vol. 140 No. 2, pp. 731-736.

Zhu, Q., Dou, Y. and Sarkis, J. (2010), “A portfolio-based analysis for green supplier management using the analytical network process", Supply Chain Management: An International fournal, Vol. 15 No. 4, pp. 306-319.

\section{Further reading}

Pathak, S.D., Day, J.M., Nair, A., Sawaya, W.J. and Kristal, M.M. (2007), "Complexity and adaptivity in supply networks: building supply network theory using a complex adaptive systems perspective", Decision Sciences, Vol. 38 No. 4, pp. 547-580.

\section{About the authors}

Anthony Alexander is an ESRC/BAM Doctoral Research Fellow for Sustainable Supply Chain Management at Cardiff Business School. He is a former sustainability director for an engineering consultancy and operations manager in the communications sector. Anthony Alexander is a corresponding author and can be contacted at: AlexanderA@cardiff.ac.uk

Helen Walker is Chair in Operations and Supply Management at Cardiff Business School. Her research focuses on sustainable supply chain management and sustainable public procurement.

Mohamed Naim is the Deputy Dean at Cardiff Business School. He is also a co-director of the Logistics Systems Dynamics Group and the Centre for Advanced Manufacturing Systems at Cardiff (CAMSAC).

To purchase reprints of this article please e-mail: reprints@emeraldinsight.com

Or visit our web site for further details: www.emeraldinsight.com/reprints 